\title{
Synthesis of Indolo[3,2-b]carbazole based boron complexes with tunable photophysical and electrochemical properties
}

Soumyaditya Mula, Nicolas Leclerc, Patrick Leveque, Pascal Retailleau, and Gilles Ulrich J. Org. Chem., Just Accepted Manuscript • DOI: 10.1021/acs.joc.8b01948 • Publication Date (Web): 02 Nov 2018 Downloaded from http://pubs.acs.org on November 2, 2018

\section{Just Accepted}

"Just Accepted" manuscripts have been peer-reviewed and accepted for publication. They are posted online prior to technical editing, formatting for publication and author proofing. The American Chemical Society provides "Just Accepted" as a service to the research community to expedite the dissemination of scientific material as soon as possible after acceptance. "Just Accepted" manuscripts appear in full in PDF format accompanied by an HTML abstract. "Just Accepted" manuscripts have been fully peer reviewed, but should not be considered the official version of record. They are citable by the Digital Object Identifier (DOI®). "Just Accepted" is an optional service offered to authors. Therefore, the "Just Accepted" Web site may not include all articles that will be published in the journal. After a manuscript is technically edited and formatted, it will be removed from the "Just Accepted" Web site and published as an ASAP article. Note that technical editing may introduce minor changes to the manuscript text and/or graphics which could affect content, and all legal disclaimers and ethical guidelines that apply to the journal pertain. ACS cannot be held responsible for errors or consequences arising from the use of information contained in these "Just Accepted" manuscripts. 


\title{
Synthesis of Indolo[3,2-b]carbazole based boron complexes with tunable photophysical and electrochemical properties
}

\author{
Soumyaditya Mula, ${ }^{\dagger,},{ }^{*}$ Nicolas Leclerc, ${ }^{\dagger},{ }^{*}$ Patrick Lévêque, ${ }^{\#}$ Pascal Retailleau, ${ }^{\perp}$ Gilles Ulrich ${ }^{\dagger, *}$ \\ †Institut de chimie et procédés pour l'énergie, l'environnement et la santé (ICPEES), UMR CNRS 7515, Ecole \\ Européenne de Chimie, Polymères et Matériaux (ECPM), 25 Rue Becquerel, Strasbourg 67087 Cedex 2, France. \\ $\$$ Current Address: Bio-Organic Division, Bhabha Atomic Research Centre, Mumbai 400085, India. \\ and Homi Bhabha National Institute, Anushakti Nagar, Mumbai 400094, India. \\ "Le laboratoire des sciences de l'ingénieur, de l'informatique et de l'imagerie (ICube), UMR7357, Université de \\ Strasbourg-CNRS, 23 rue du Loess, 67037 Strasbourg, France. \\ ${ }^{\perp}$ Centre de Recherche de Gif, Institut de Chimie des Substances Naturelles, CNRS, Bât. 27-1 avenue de la Terrasse, \\ 91198 Gif-sur-Yvette Cedex, France. \\ Corresponding author’s e-mail address: smula@barc.gov.in (SM); leclercn@unistra.fr (NL); gulrich@unistra.fr (GU)
}


Table of Content:

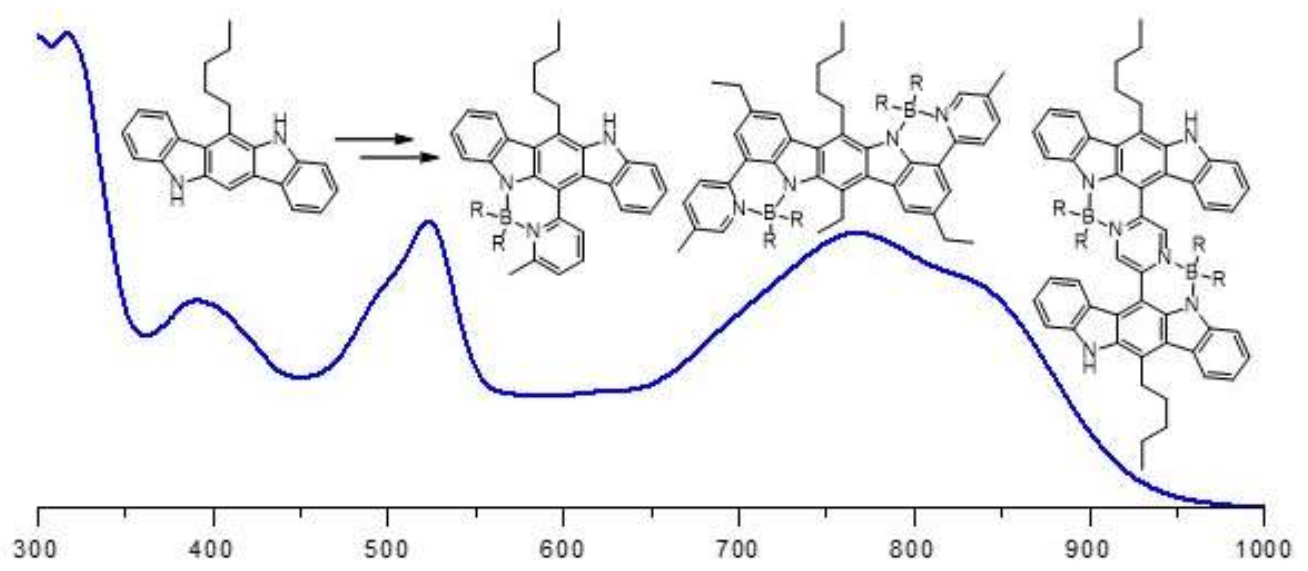

\begin{abstract}
New synthetic strategies were developed for the synthesis of indolo-pyridine boron difluoride (IPBD) dyes and anti-ladder-type $\pi$-conjugated dyes based on the pyridine/pyrazineindolocarbazole (ICZ) structures. The photophysical and electrochemical properties of the dyes were measured in solution, solid state and thin films, and rationalized by theoretical calculations. Interestingly, these properties of the dyes can be tuned in a wide range using the developed chemical route. For example, the absorption range and fluorescence colour of the dyes in solution and solid state, and the HOMO-LUMO energy gaps were tuned by structure modulations. The absorption properties of those new boron-complexes cover most of the UV-visible-NIR spectrum. Therefore, this appealing tunability feature makes these new types of dyes very promising candidates for their further use in functional material development.
\end{abstract}




\section{Introduction:}

Organic conjugated frameworks containing boron atom are very promising for the development of new functional materials with outstanding photophysical and electronic properties. ${ }^{1-8}$ The boron atom improves the performance of organic electronics by acting as a conduit for the $\pi$-conjugated skeleton and substantially decreasing the energy of the lowest unoccupied molecular orbital (LUMO). This immense potential motivated the search for new $\pi$ conjugated bidentate ligands to provide boron complexes with promising electronic and optical properties. BODIPY dyes are classical examples of such type of compounds. ${ }^{9-10}$ It is well established that the small organic molecules based on BODIPYs are very efficient components of the active layer of organic optoelectronic devices, such as organic photovoltaic cells (OPV), ${ }^{8,11-15}$ or organic lasers. ${ }^{16-17}$ Anilido-pyridine boron difluorides (APBDs) are another class of highly promising compounds, which exhibit high emission quantum yields and large Stokes shifts but very few reports are available to date. ${ }^{18-20}$

Indolo[3,2- $b]$ carbazoles (ICZs) ${ }^{21}$ are widely studied because of their many interesting properties which made them useful for a large range of applications such as sensing, ${ }^{22}$ biological studies $^{23-25}$ and specially in organic electronics. Indeed, high charge carrier mobilities, electronic levels tuning, good stability towards atmospheric conditions makes them ideal components for use in organic field effect transistors (OFETs), ${ }^{26-28}$ organic light emitting diodes (OLEDs), ${ }^{29-31}$ Dye Sensitised Solar Cells (DSSCs) ${ }^{32}$ and even in OPVs. ${ }^{33-36}$ Thus, it was anticipated that the incorporation of the boron atom in the ICZ moiety may further improve its interest for organic electronics. Despite of recent advances, examples of the incorporation of boron atoms into ICZs molecular frame are rare. ${ }^{37}$

5,11-dihydroindolo[3,2-b]carbazole (A, Chart 1), having two inbuilt indolo functions, are nice platforms to synthesize indolo-pyridine boron difluoride (IPBD) dyes similar to APBD dyes. Development of synthetic strategies to insert pyridine moiety at the $\mathrm{C} 4, \mathrm{C} 10$ and $\mathrm{C} 12$ positions of A enable the synthesis of different bidentate ligands based on indolo-pyridine skeletons viz. B and C (Chart 1). Using similar chemical strategies, a more sophisticated ladder-type ligand can also be synthesized by linking one pyrazine molecule with two ICZ, A through their C12 positions. Further, boron coordination with these ligands will allow effective $\pi$-delocalization of the ICZs moiety and reinforce the compounds interest for material science. Till now, only one report on ICZs based APBD dye is available in the literature. ${ }^{37}$ Herein we report, three different types of 
APBD dyes based on the pyridine-ICZ structures and three anti-ladder-type $\pi$-conjugated dyes based on the pyrazine-ICZ structures. Their detailed photophysical and electrochemical properties were evaluated and discussed for their further use in functional materials developments.

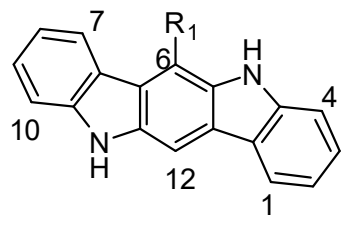

A<smiles>[R]c1cnc(-c2c3[nH]c4ccccc4c3c([R])c3[nH]c4ccccc4c23)cc1[X]</smiles>

B<smiles>[R5]c1cc(-c2ccccn2)c2[nH]c3c([R])c4c([nH]c5c(-c6cccc([R6])n6)cc([R5])cc54)c([R])c3c2c1</smiles>

C

Chart 1. Chemical structure of ICZ (A) and indolo-pyridine type ligands $(\mathbf{B}, \mathbf{C})$ based on ICZ.

\section{Results and Discussion:}

Synthesis. The synthesis started with ICZ, 6-Pentyl-5,11-dihydroindolo[3,2-b]carbazole (1) which was synthesized according to the reported method. ${ }^{38-39}$ At first, functionalization at the $\mathrm{C} 12$ position of $\mathbf{1}$ was attempted to synthesize $\mathbf{B}$-type ligands. Controlled bromination of $\mathbf{1}$ using $\mathrm{FeBr}_{3}$ furnished 6-Bromo-12-pentyl-5,11-dihydroindolo[3,2- $b$ ]carbazole (2) in a very good yield. ${ }^{39}$ Then borylation of 2 with pinacolborane provided 6-Boryl-12-pentyl-5,11-dihydroindolo[3,2$b$ ]carbazole (3). The Suzuki-Miyuara coupling reaction of $\mathbf{3}$ with bromopyridine afforded $\mathbf{B}$ type ligand 4. Finally, treatment of 4 with excess $\mathrm{BF}_{3} \cdot \mathrm{OEt}_{2}$ and $\mathrm{B}(\mathrm{Ph})_{3}$ separately furnished the corresponding dyes $\mathbf{5 a}$ and $\mathbf{5 b}$, respectively (Scheme 1). 

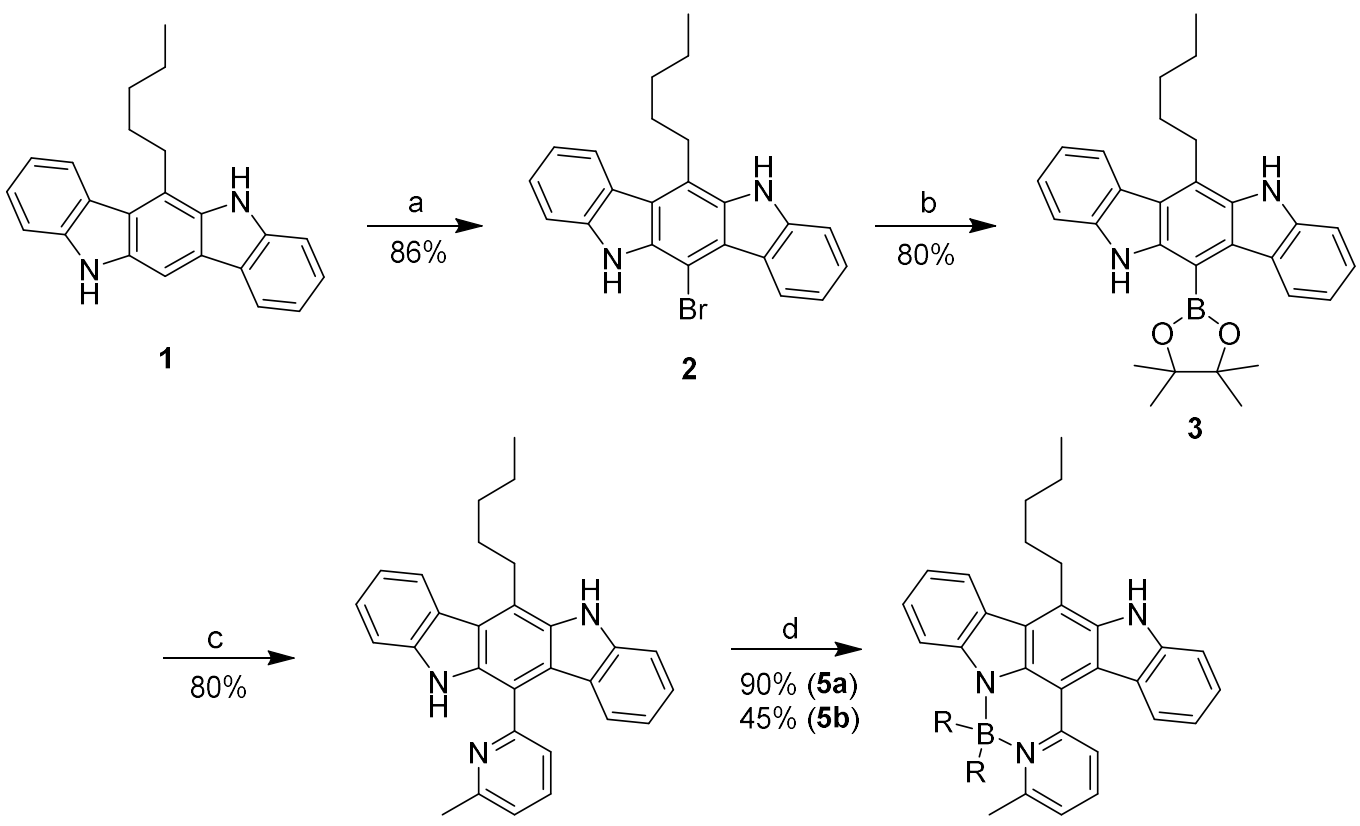

4

5a. $R=F$

5b. $\mathrm{R}=\mathrm{Ph}$

Scheme 1. Synthesis of dye 5a-b. a) $\mathrm{FeBr}_{3}$ (3 equiv.), THF: $\mathrm{H}_{2} \mathrm{O}$ (5:2), $25{ }^{\circ} \mathrm{C}, 20$ h. b) Pinacolborane, $\mathrm{Pd}\left(\mathrm{PPh}_{3}\right)_{2} \mathrm{Cl}_{2}$, 1,4-Dioxane, $100{ }^{\circ} \mathrm{C}, 12$ h. c) 2-Bromo-5-methylpyridine, $\mathrm{Pd}\left(\mathrm{PPh}_{3}\right)_{4}, \mathrm{Cs}_{2} \mathrm{CO}_{3}, \mathrm{CsF}$, Toluene/DMF (2:1), $90{ }^{\circ} \mathrm{C}, 12$ h. d) $\mathrm{Et}_{3} \mathrm{~N}, \mathrm{BF}_{3} . \mathrm{OEt}_{2}, \mathrm{DCE}, 80{ }^{\circ} \mathrm{C}, 12 \mathrm{~h}$ (for 5a); $\mathrm{B}(\mathrm{Ph})_{3}$, Toluene, $90{ }^{\circ} \mathrm{C}, 12 \mathrm{~h}$ (for $\mathbf{5 b}$ ).

Dye 5a was characterized by NMR spectroscopy giving well-defined spectra in $\left(\mathrm{CD}_{3}\right)_{2} \mathrm{CO}$. For example, ${ }^{1} \mathrm{H}$ NMR spectrum (Figure S8) showed signals for all aromatic protons along with a singlet at $10.84 \mathrm{ppm}$ for the N-H proton. The benzylic methylene and terminal methyl groups of the pentyl lateral chain resonates as triplets at 3.67 and $0.92 \mathrm{ppm}$, respectively. Other three internal methylene groups signal of pentyl lateral chain were found as three different multiplets centred at $2.00,1.67$ and $1.46 \mathrm{ppm}$ with the expected two protons integration for each signal. Another diagnostic signal is provided by the benzylic methyl group of the pyridine moiety at $3.16 \mathrm{ppm}$ which appeared as a triplet $(J=3.2 \mathrm{~Hz})$ due to coupling with $\mathrm{F}$ atom of the $\mathrm{BF}_{2}$ group. The carbon spectra presented the expected six signals for the alkyl atoms and the expected 23 signals for aromatic atoms (Figure $\mathrm{S} 9$ ). 

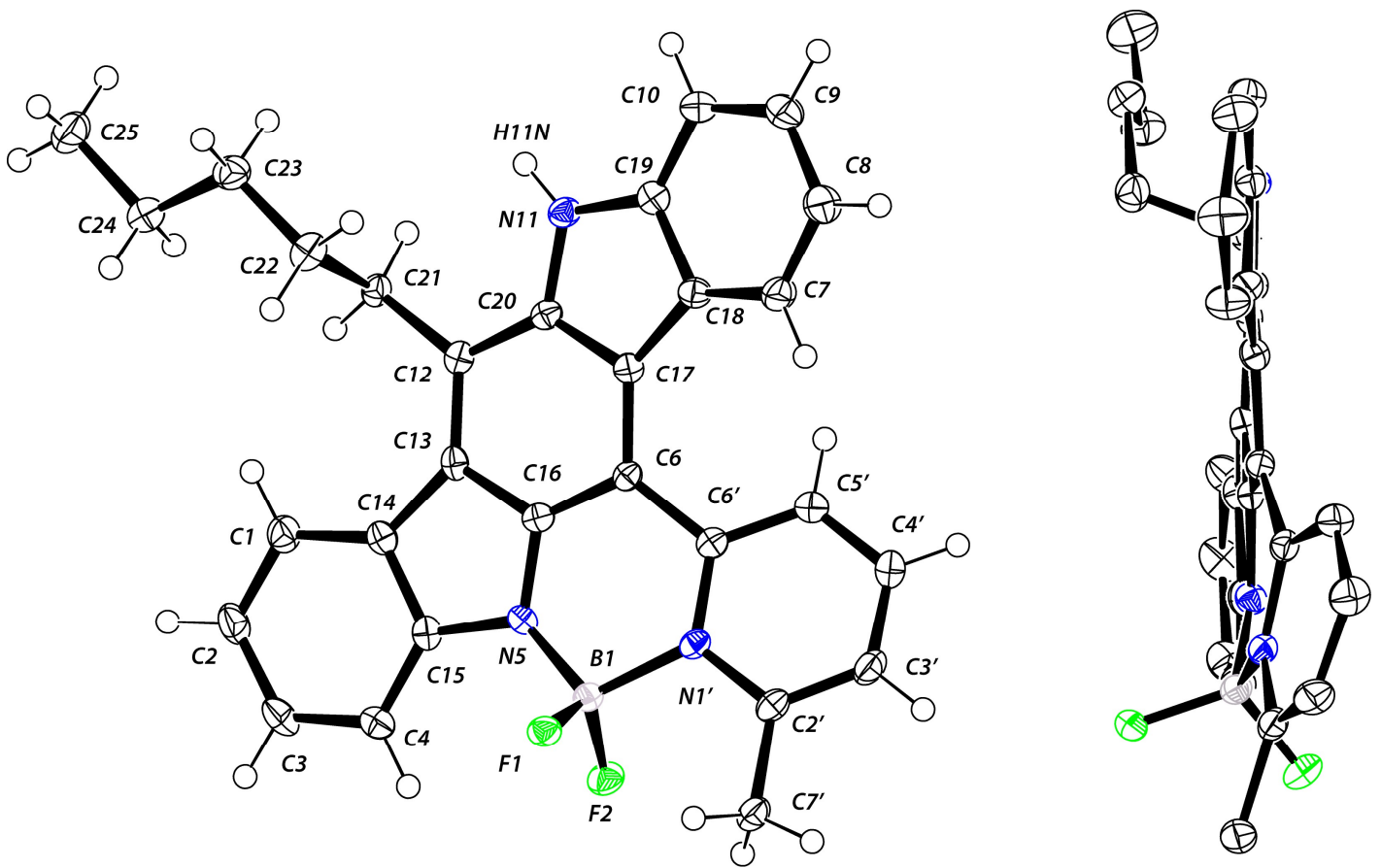

Figure 1. Two orthogonal Ortep views of the crystal structure of compound 5a.

Moreover, the structure of 5a was confirmed by X-ray crystallography data (Figure 1). It is important to mention that the indolocarbazole moiety lost its planarity after the chelation of the boron atom (the rms deviation for fifteen atoms of the framework is $0.069 \AA$ when the tail represented by C7, C8 and C9 atoms is lifted out of the plane by max. $0.56 \AA$ ). The pyridyl ring is also twisted out of the hypothetical plane containing the ICZ aromatic core (torsion angle $\mathrm{C} 17 / \mathrm{C} 6 / \mathrm{C}^{\prime} / \mathrm{C}^{\prime}$ ' of $-18.79^{\circ}$ ). This is probably due to the van der Waals interactions of the protons at C7 and C5' carbon atoms of ICZ and pyridyl moieties, respectively. This has for consequence to bring a slight conformational helicity to the molecule that becomes de facto a chiral object. At the opposite side, the pentyl unit counterbalances the twist making a dihedral angle $(\mathrm{C} 13 / \mathrm{C} 12 / \mathrm{C} 21 / \mathrm{C} 22)$ with the ICZ moiety of $95.9^{\circ}$, and the all-trans configured butyl chain $\left((\mathrm{C} 21 / \mathrm{C} 22 / \mathrm{C} 23 / \mathrm{C} 24)\right.$ adopting a gauche conformation $\left.\left(72.0^{\circ}\right)\right)$ nearly lies in a plane parallel to that of the aromatic system.

As observed elsewhere ${ }^{37}$ for a similar structure, the B-N bond is sensibly longer for the pyridine (1.618 (3) $\AA$ ) than for the indolocarbazole (1.504 (3) $\AA$ ). If the B-F distances look more similar, the H-bond interaction from the amine group of a vicinal molecule in $1 / 2-\mathrm{x}, \mathrm{y}, 1 / 2+\mathrm{z}$ position with F1 (d N11 - H11 ... F1, 2.11 (3) $\AA$ ) extended the relevant bond to 1.407 (3) $\AA$ in the $c$ 
direction. The boron atom presents as usual for $F$-BODIPY analogues a slight distorted tetrahedral environment with bond angles ranging from 107.82 to $111.51^{\circ}$ and typical values of $108.15(17)^{\circ}$ for $\mathrm{N}-\mathrm{B}-\mathrm{N}$ and $109.23(18)^{\circ}$ for $\mathrm{F}-\mathrm{B}-\mathrm{F}$. The double bond localization seems to encompass the N5-C16, N1'-C6', N1'-C2' bonds (average distances of $1.38 \AA$ ) in contrast with the $1.40 \AA$ and more distances observed for $\mathrm{N} 5-\mathrm{C} 15, \mathrm{C} 16-\mathrm{C} 6, \mathrm{C} 6$ '- 6 , and $\mathrm{C} 6$ '-C5' in particular.

The overall conformation of the molecules looks planar and therefore it is not surprising to see them assembled parallel to the plane $\left(\begin{array}{lll}0 & 0 & 1\end{array}\right)$ making infinite layers with $3.95 \AA$ interplanar distances (Figure 2, left). Along the orthogonal direction coinciding with the chirality axis, the molecules pile up in columnar way with shortest centroid-centroid distances (3.9616 (14) $\AA$ ) involving the central indole groups. However, the alternation of the enantiomeric helices related by the glide mirror $\boldsymbol{a}$ prevents from the formation of super-helical assembly inside the crystal.
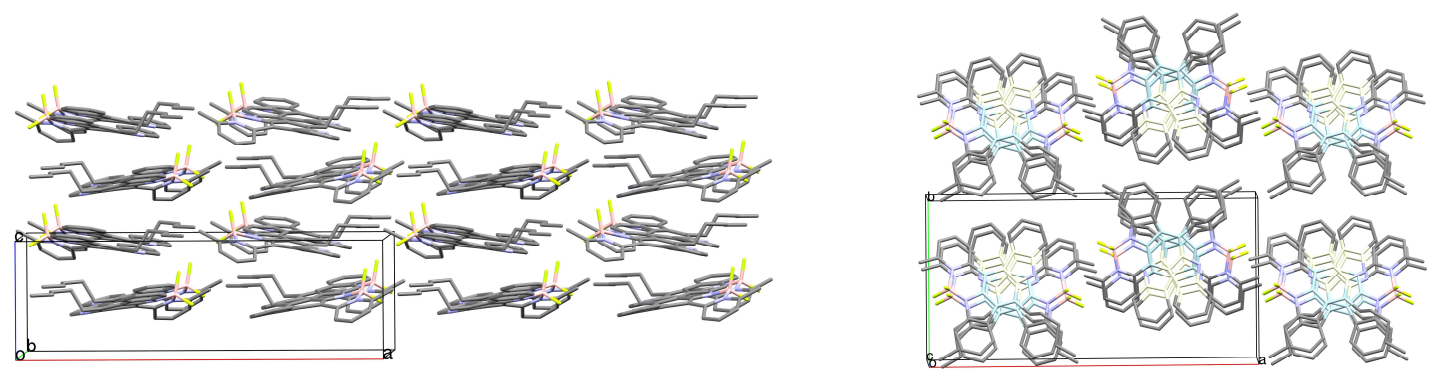

Figure 2. (Left) A packing diagram for $5 \mathbf{a}$ viewed along the $\boldsymbol{b}$ axis, showing the layer formation parallel to the plane. (Right) View down the $c$ axis showing the columns through $\pi-\pi$ stacking involving the adjacent central indole moieties (in light blue and grey).

Next, we aimed to synthesize anti-ladder type complexes starting from 6-Boryl-ICZ (3). The Suzuki-Miyuara coupling reaction of 2,5-dibromopyrazine with two molecules of $\mathbf{3}$ afforded the ligand $\mathbf{6}$ with two chelating sites. Then, controlled reaction of 6 with $\mathrm{BF}_{3} \cdot \mathrm{OEt}_{2}$ furnished mono$\mathrm{BF}_{2}$ complex $7 \mathbf{a}$ (with 1 eq. $\mathrm{BF}_{3} \cdot \mathrm{OEt}_{2}$ ) and bis- $\mathrm{BF}_{2}$ complex 8 (with excess $\mathrm{BF}_{3} \cdot \mathrm{OEt}_{2}$ ) (Scheme 2). Unfortunately, only mono- $\mathrm{BPh}_{2}$ complex, $7 \mathbf{b}$ was obtained even after prolonged heating of $\mathbf{6}$ with excess $\mathrm{B}(\mathrm{Ph})_{3}$. Steric bulkiness and twisting of the molecules probably hindered the complexation of the $2^{\text {nd }}-\mathrm{BPh}_{2}$ moiety with $7 \mathbf{b}$. 

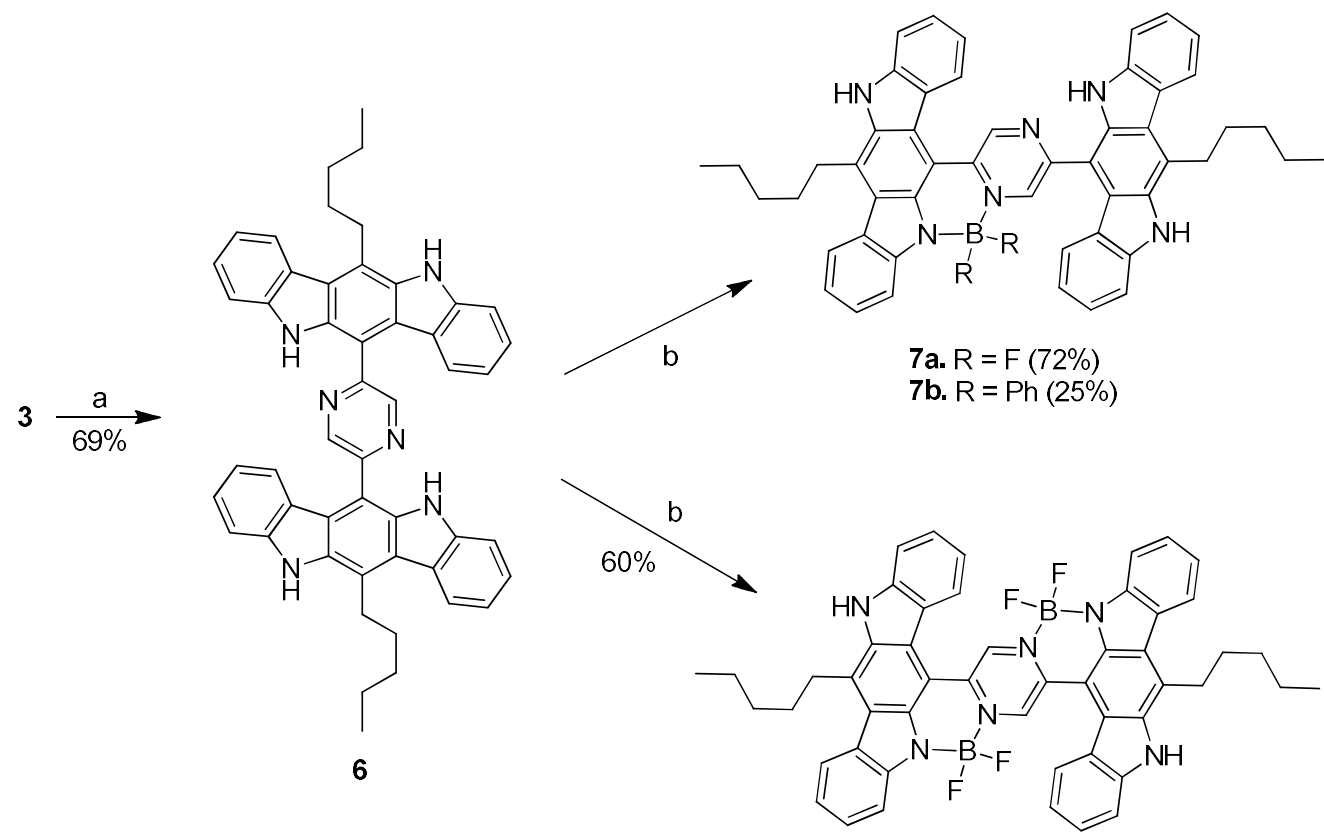

8

Scheme 2. Synthesis of dyes 7a-b and 8. a) 2,5-Dibromopyrrazine, $\mathrm{Pd}\left(\mathrm{PPh}_{3}\right)_{4}, \mathrm{Cs}_{2} \mathrm{CO}_{3}, \mathrm{CsF}$, Toluene/DMF (2:1), $90{ }^{\circ} \mathrm{C}, 12$ h. b) $\mathrm{Et}_{3} \mathrm{~N}, \mathrm{BF}_{3} . \mathrm{OEt}_{2}, \mathrm{DCE}, 80^{\circ} \mathrm{C}, 12 \mathrm{~h}$ (for $\left.7 \mathbf{a}\right) / 48 \mathrm{~h}$ (for 8); B(Ph) 3 , Toluene, $90^{\circ} \mathrm{C}, 48 \mathrm{~h}$ (for $7 \mathbf{b}$ ).

All the complexes, $\mathbf{7 a - b}$ and $\mathbf{8}$ were fully characterized by NMR and mass spectroscopy. For example, compound 7a was identified by the diagonastic 5 singlets in ${ }^{1} \mathrm{H}$ NMR at 9.13, 10.53, 11.07, 11.35, 11.95 ppm corresponding to three N-H and two pyrazine C-H protons (Figure S15 and S20). Due to the dissymmetry of the structure, all these peaks appeared as well separated singlets. Other diagonostic signals to confirm the 7a structure were given by the benzylic methylene groups of the pentyl chains which resonated at 3.62 and $3.72 \mathrm{ppm}$ as two separate triplets for two protons each. In contrast, the symmetry of the compound $\mathbf{8}$ was observed nicely in ${ }^{1} \mathrm{H}$ NMR spectrum. For example, two pyrrazine C-H and two indole N-H protons resonates at 10.17 and 12.03 ppm, respectively as singlets. Two benzylic methylene groups of the pentyl chains also appeared as a triplet for 4 protons at 3.70 ppm (Figure S19 and S20). 
Lastly, we aimed to functionalize the ICZ through C-4 and C-10 positions which are less reactive in nucleophilic substitutions as compared to $\mathrm{C}-2, \mathrm{C}-8$ and $\mathrm{C}-12$ positions for the synthesis of C-type ligand. ${ }^{38}$ Thus, first hurdle was to block these later positions with alkyl groups. The synthesis was started with 2,8-dibromo-6-pentyl-5,11-dihydroindolo[3,2-b]carbazole (9) which was synthesized using a reported method. ${ }^{39}$ Selective bromination using $\mathrm{FeBr}_{3}$ furnished tribromo ICZ (10) in excellent yield (Scheme 3). Then, 10 was subjected to Sonogashira coupling with trimethylsilylacetylene to furnish acetylene substituted ICZ, 11. The silyl groups were knocked off by $\mathrm{K}_{2} \mathrm{CO}_{3}$ mediated reaction and the acetylene group was reduced to ethyl by metal induced hydrogenation reaction to furnish 2,8,12-triethyl substituted ICZ, 13. Bromination of 13 with $\mathrm{Br}_{2}$ in $\mathrm{AcOH}$ furnished 4,10-dibromo ICZ, 14 in excellent yield. Then borylation of $\mathbf{1 4}$ with pinacolborane provided 4,10-diboryl-2,8,12-triethyl-6-pentyl-5,11-dihydroindolo[3,2-b]carbazole (15). The Suzuki-Miyaura coupling reaction of 15 with 2-Bromo-5-methylpyridine afforded the ligand, which was simultaneously treated (two-fold reaction) with excess $\mathrm{BF}_{3} \cdot \mathrm{OEt}_{2}$ to furnish the corresponding dye 16. The dye was characterized by NMR and mass spectrometry. 

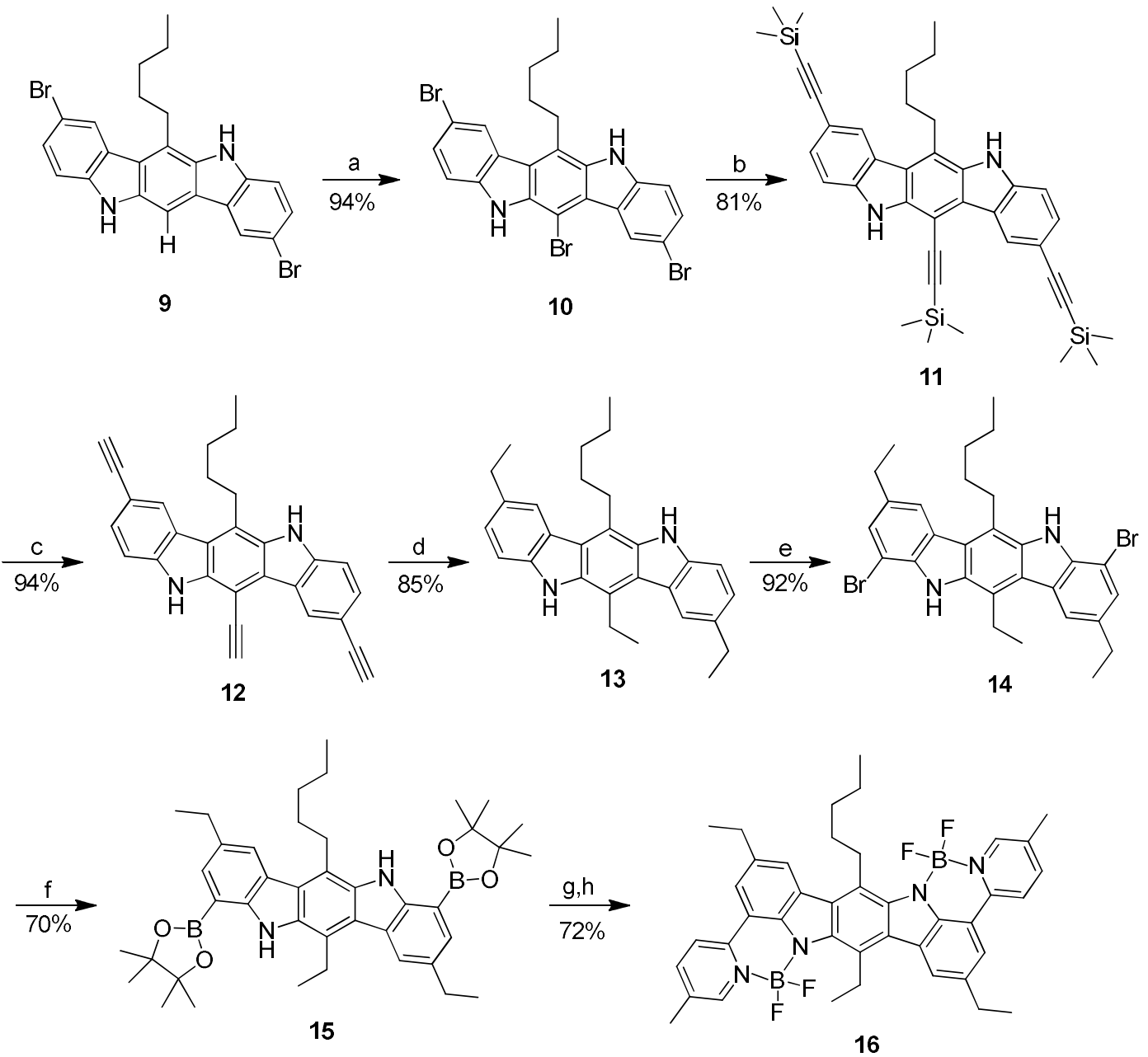

Scheme 3. Synthesis of dye 16. a) $\mathrm{FeBr}_{3}$ (3 equiv.), THF: $\mathrm{H}_{2} \mathrm{O}(5: 2), 25{ }^{\circ} \mathrm{C}, 20$ h. b) Trymethylsilylacetylene, $\mathrm{Pd}(\mathrm{dppf})_{2} \mathrm{Cl}_{2}$. DCM, CuI, Diisopropyl amine, Toluene, $110^{\circ} \mathrm{C}, 12 \mathrm{~h}$. c) $\mathrm{K}_{2} \mathrm{CO}_{3}, \mathrm{DCM} / \mathrm{MeOH}(1: 1), 25^{\circ} \mathrm{C}, 14$ h. d) $\mathrm{H}_{2}, \mathrm{Pd} / \mathrm{C}, \mathrm{DCM} / \mathrm{EtOH}(1: 1), 50^{\circ} \mathrm{C}, 12$ h. e) $\mathrm{Br}_{2}, \mathrm{AcOH}$, $100{ }^{\circ} \mathrm{C}, 2$ h. f) Pinacolborane, $\mathrm{Pd}\left(\mathrm{PPh}_{3}\right)_{2} \mathrm{Cl}_{2}$, 1,4-Dioxane, $100{ }^{\circ} \mathrm{C}, 12$ h. g) 2-Bromo-5methylpyridine, $\mathrm{Pd}\left(\mathrm{PPh}_{3}\right)_{4}, \mathrm{Cs}_{2} \mathrm{CO}_{3}$, CsF, Toluene/DMF (2:1), $90{ }^{\circ} \mathrm{C}, 12$ h. h) $\mathrm{Et}_{3} \mathrm{~N}, \mathrm{BF}_{3} \cdot \mathrm{OEt}_{2}$, DCE, $80{ }^{\circ} \mathrm{C}, 12 \mathrm{~h}$. 
Photophysical properties. The photophysical properties of the dyes 5a-b, 7a-b, 8 and $\mathbf{1 6}$ in DCM, solid states and thin films were evaluated at room temperature $\left(25{ }^{\circ} \mathrm{C}\right)$. The measured photophysical parameters (absorption maximum $\left(\lambda_{\mathrm{abs}}\right)$, emission maximum $\left(\lambda_{\mathrm{em}}\right)$, maximum molar absorptivity ( $\left.\varepsilon_{\max }\right)$ and fluorescence quantum yield $\left(\Phi_{\mathrm{fl}}\right)$ ) and the calculated Stokes shift $(v)$ of the dyes in DCM and thin films are presented in Table 1. The absorption, emission and excitation spectra of dyes 5a and 5b in DCM are shown in Figure S36 and S37. Absorption spectra of both the dyes showed multiple peaks with the longest wavelength absorption maximum $(\lambda \max )\left(\mathrm{S}_{0} \rightarrow \mathrm{S}_{1}\right.$ absorption band) at $493 \mathrm{~nm}$ and $516 \mathrm{~nm}$ for $\mathbf{5 a}$ and $\mathbf{5 b}$, respectively. In thin films, due to intermolecular $\pi$-stacking, the absorption bands of both the dyes $\mathbf{5 a}$ and $\mathbf{5 b}$ are red shifted with $\lambda_{\max }$ at 508 and $529 \mathrm{~nm}$, respectively (Figure S36 and S37). Both dyes were weakly fluorescent with $\lambda_{\mathrm{em}}$ at $562 \mathrm{~nm}$ and $578 \mathrm{~nm}$ for $\mathbf{5 a}$ and $\mathbf{5 b}$, respectively i.e. the Stokes shifts of both the dyes were high. It was noticed that both $\lambda_{\max }$ in solution as well as in film and $\lambda_{\mathrm{em}}$ of $\mathbf{5 b}$ were red shifted by 21-23 $\mathrm{nm}$ as compared to those of $\mathbf{5 a}$. These features clearly revealed that the substitution of the F-groups at the B-atom with the phenyl had significant bathochromic effect on the optical properties of the ICZ-based dye as seen in BODIPY dyes previously. ${ }^{14}$ 
Table 1. Photophysical properties of dyes $5 \mathbf{a}-\mathbf{b}, 7 \mathbf{a}-\mathbf{b}, \mathbf{8}$ and $\mathbf{1 6}$ in DCM and thin films.

\begin{tabular}{|c|c|c|c|c|c|c|c|}
\hline Dye & $\lambda_{\text {abs }}[\mathrm{nm}]$ & $\lambda_{\text {abs }}[\mathrm{nm}]$-film & $\varepsilon_{\max }\left[\mathrm{M}^{-1} \mathrm{~cm}^{-1}\right]$ & $\lambda_{\mathrm{em}}[\mathrm{nm}]$ & $v\left[\mathrm{~cm}^{-1}\right]$ & $\Phi_{\mathrm{fl}}{ }^{[\mathrm{a}]}$ & $\Delta E g_{\text {opt }}(\mathrm{eV})$ \\
\hline \multirow[t]{4}{*}{$5 a$} & 268 & & 36000 & 562 & 2500 & 0.01 & \multirow{4}{*}{2.2} \\
\hline & 314 & 319 & 18400 & & & & \\
\hline & 404 & 414 & 14400 & & & & \\
\hline & 493 & 508 & 16600 & & & & \\
\hline \multirow[t]{4}{*}{$5 b$} & 270 & & 70300 & 578 & 2100 & 0.003 & \multirow{4}{*}{2.1} \\
\hline & 321 & 327 & 32300 & & & & \\
\hline & 389 & 406 & 23000 & & & & \\
\hline & 516 & 529 & 18600 & & & & \\
\hline \multirow[t]{3}{*}{$7 \mathbf{a}$} & 309 & & 29800 & - & - & - & \multirow{3}{*}{1.7} \\
\hline & 443 & 459 & 12200 & & & & \\
\hline & 587 & 614 & 21600 & & & & \\
\hline \multirow[t]{3}{*}{$7 b$} & 256 & & 69200 & - & - & - & \multirow{3}{*}{1.6} \\
\hline & 443 & 463 & 14900 & & & & \\
\hline & 613 & 641 & 22500 & & & & \\
\hline \multirow[t]{4}{*}{8} & 317 & & 34700 & - & - & - & \multirow{4}{*}{1.03} \\
\hline & 523 & 540 & 21000 & & & & \\
\hline & 767 & 809 & 20100 & & & & \\
\hline & 845 & 910 & 15700 & & & & \\
\hline \multirow[t]{4}{*}{16} & 260 & & 57700 & 617 & 3600 & 0.01 & \multirow{4}{*}{2.2} \\
\hline & 317 & & 36700 & & & & \\
\hline & 336 & 343 & 39300 & & & & \\
\hline & 506 & 517 & 28600 & & & & \\
\hline
\end{tabular}

aDetermined using $\Phi_{\mathrm{fl}}=0.88$ for Rhodamine $6 \mathrm{G}$ in ethanol as the reference. ${ }^{40}$ 
The absorption spectra of dyes 7a-b and $\mathbf{8}$ in DCM are shown in Figure S38. Both the dyes 7a and $7 \mathbf{b}$ showed several absorption peaks with $\lambda_{\max }\left(\mathrm{S}_{0} \rightarrow \mathrm{S}_{1}\right.$ absorption band $)$ at 587 and $613 \mathrm{~nm}$, respectively (Table 1). It is important to mention that the $\lambda_{\max }$ of $7 \mathbf{a}$ and $\mathbf{7 b}$ are red shifted by 94 and $97 \mathrm{~nm}$ respectively with respect to the $\lambda_{\max }$ of $\mathbf{5 a}$ and $\mathbf{5 b}$. The substitution effect of the Fgroups at the B-atom with the phenyl (as seen in case of $\mathbf{5 a}$ and $\mathbf{5 b}$ ) is also clearly visible in $\mathbf{7 b}$ as its $\lambda_{\max }$ is red shifted by $26 \mathrm{~nm}$ compared to that of $7 \mathbf{a}$. The absorption spectrum of $\mathbf{8}$ is further red shifted due to its more planar structure and the presence of the two B-atoms. More importantly the absorption spectrum of $\mathbf{8}$ extends over the whole UV-visible and near infra-red region. The $\lambda_{\max }$ (845 nm) of dye 8 is red shifted by $352 \mathrm{~nm}$ and $254 \mathrm{~nm}$ with respect to the $\lambda_{\max }$ of $\mathbf{5 a}$ and $7 \mathbf{a}$, respectively. In thin films, the absorption bands of the dyes $\mathbf{7 a}, \mathbf{7 b}$ and $\mathbf{8}$ are red shifted as compared to their solution absorption bands with $\lambda_{\max }$ at 614,641 and $910 \mathrm{~nm}$, respectively (Figure S38). Compound 8 in solid-state exhibits an impressive bathochromic shift with an absorption onset up to $1200 \mathrm{~nm}$ and a broad absorption band covering partly the infrared region. All the dyes $\mathbf{7 a - b}$ and $\mathbf{8}$ were completely non-fluorescent. These compounds possess an extended $\pi$-system lowering the LUMO level, flexible fatty chains attached to the aromatic core and free carbazole amines, which probably offer supplementary non-radiative deactivation pathway compared to compounds 5a-b.

The absorption, emission and excitation spectra of dye $\mathbf{1 6}$ in DCM are shown in Figure 39. The absorption spectrum is quite similar to that of $\mathbf{5 a}$ with a $13 \mathrm{~nm}$ red shift in $\lambda_{\max }$ (Table 1). This clearly indicates that the whole molecule may not be completely conjugated. In thin film the absorption band of dye $\mathbf{1 6}$ is slightly red shifted with $\lambda_{\max }$ at $517 \mathrm{~nm}$ (Figure S39). This small red shift in the solid-state highlights probably a poor solid-state $\pi$-stacking ability of this bidentate dye as compare to previous molecules. Interestingly, the $\lambda_{\mathrm{em}}$ was highly red shifted $(55 \mathrm{~nm})$ as compared to 5a with large Stokes shift $\left(3600 \mathrm{~cm}^{-1}\right)$. The dye 16 showed orange fluorescence, albeit with a low $\Phi_{\mathrm{fl} l}$.

In general, these new indolo-pyridine boron difluoride (IPBD) dyes have different properties than the APPD dyes. One drawback of APPD dyes is their low molar absorption coefficients $\left(\sim 10000 \mathrm{M}^{-1} \mathrm{~cm}^{-1}\right)$ (given in ref 18). But in the present IPBD dyes the molar absorption coefficient was significantly increased. For instance, dye $\mathbf{1 6}$ has an almost 3 times higher molar absorptivity than the carbazole based APPD dyes. Due to extended conjugation in IPBD dyes, the absorption maxima are also highly red-shifted as compared to carbazole APPD dyes. Red-Shifts 
in emission maxima are less pronounced. This resulted into low Stokes shifts in case of IPBD dyes as compared to carbazole-based APPD dyes, although the Stokes shift is still high as compared to BODIPY dyes.

Compared to structurally similar carbazole-indole BODIPY dyes published before, these simple ICZ-based boron complexes $\mathbf{5 a - 5 b}$ exhibit really close absorption features with a significant bathochromic shift in absorption and emission. ${ }^{41-44}$ The previously published carbazole-based BODIPYs were more emissive. The supplementary fused indole moiety induces a nice red-shift concomitantly with a rise of the non-radiative deactivation pathway which makes the dyes 5a-5b low fluorescent dyes.

Solid state fluorescence. The solid state fluorescence of the dyes embedded in $\mathrm{KBr}$ matrix $\left(10^{-6}\right.$ $\mathrm{M}$ microcrystalline dispersed in $\mathrm{KBr}$ pellet by grinding) was investigated. Only three dyes (5a, 5b and 16) exhibited weak but significant emission. The non-radiative deactivation pathways i.e. molecular motion/rotations are inhibited in the solid state. This probably enhances the quantum yield in the solid state. The corresponding normalized emission spectra are compiled in Figure 3a and the photographic images of the powdered dyes under UV-light are shown in Figure 3b. A trend similar to the solution emission was also observed in the solid state emission for dyes $\mathbf{5 a}$ and $\mathbf{5 b}$. Emission of $\mathbf{5 b}$ was red-shifted as compared to $\mathbf{5 a}$ with $\lambda_{\mathrm{em}}$ of 624 and $586 \mathrm{~nm}$ respectively i.e. red-shift of $1300 \mathrm{~cm}^{-1}$ and $730 \mathrm{~cm}^{-1}$ in solid state. Interestingly, the fluorescence quantum yields ( $\Phi_{\mathrm{fl}}=3.2$ and $1.4 \%$ for $\mathbf{5 a}$ and $\mathbf{5 b}$, respectively as recorded with integration sphere as $\mathrm{KBr}$ pellets) are higher than the one recorded in solution. In case of dye 16, slight red-shift in the emission $\left(\lambda_{\text {em }}\right.$ $=602 \mathrm{~nm}$ ) as compared to dye $\mathbf{5 a}$ was observed confirming the poor delocalization over the whole molecule. But 16 was more fluorescent in the solid state $\left(\Phi_{\mathrm{fl}}=4 \%\right)$ than both $\mathbf{5 a}$ and $\mathbf{5 b}$. 
(a)

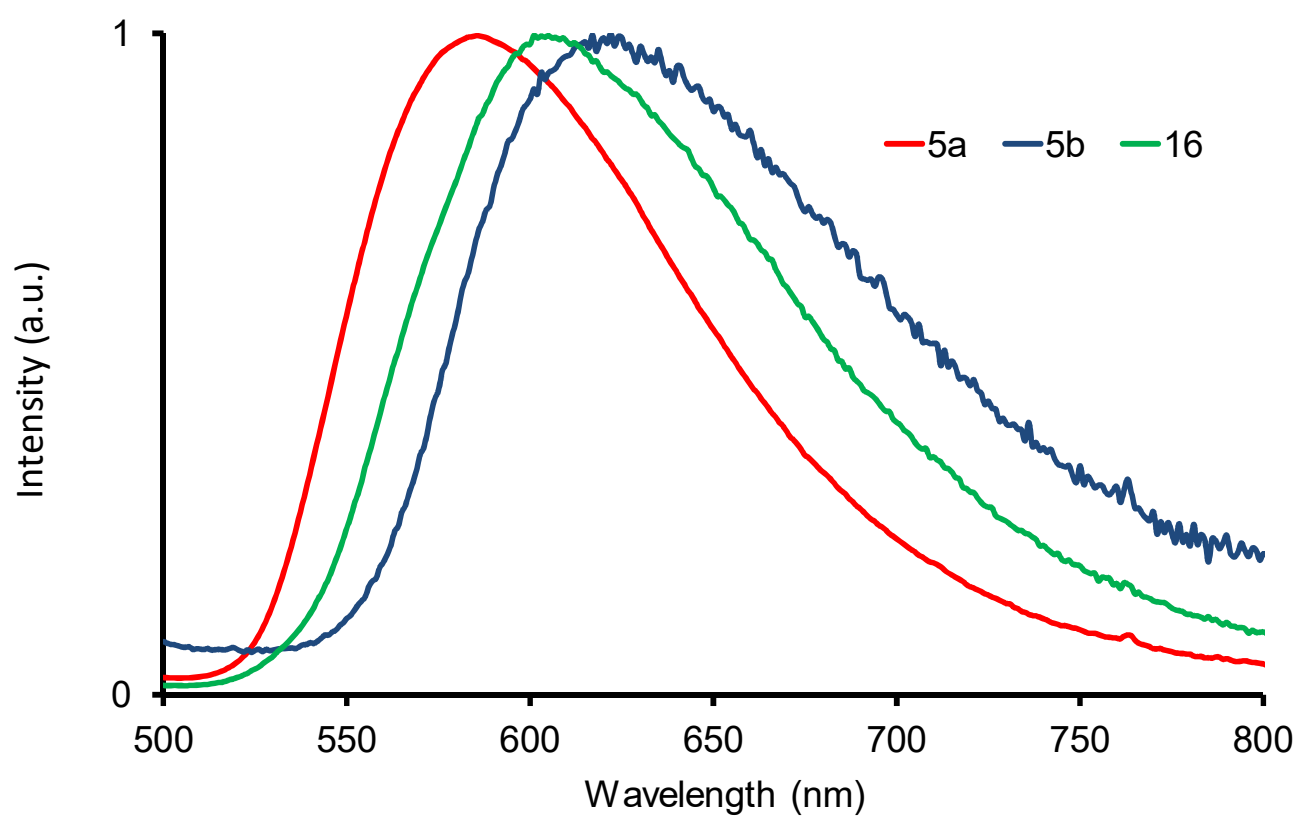

(b)

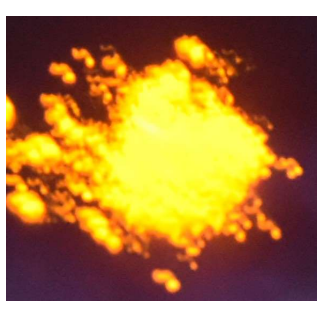

5a

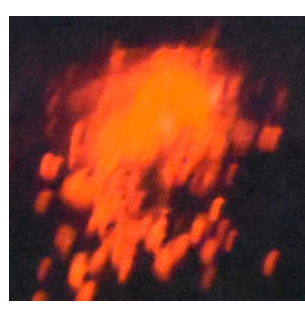

5b

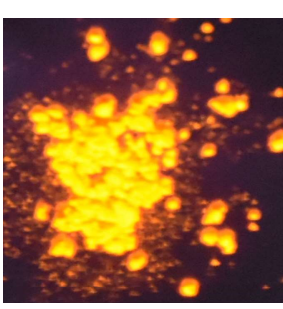

16

Figure 3. (a) Solid state spectra of dyes $\mathbf{5 a}$ (red), $\mathbf{5 b}$ (blue) and $\mathbf{1 6}$ (green), embedded in $\mathrm{KBr}$ matrix, $10^{-6} \mathrm{M}$ solid solution. (b) Photographic images of the powdered dyes 5a, 5b and $\mathbf{1 6}$ under UV light $(\lambda=365 \mathrm{~nm})$.

Cyclic voltammetry (CV). Cyclic voltammetry of 4, 5a-b, 7a-b, 8 and 16 were carried out in DCM solutions to investigate their oxidation and reduction processes as well as to determine the energies of their highest occupied molecular orbital (HOMO) and lower unoccupied molecular orbital (LUMO) levels. All the redox potentials were calibrated with respect to ferrocene (Fc), assuming that $\mathrm{E}_{1 / 2}\left(\mathrm{Fc} / \mathrm{Fc}^{+}\right)=0.38 \mathrm{~V}$ referred to $\mathrm{SCE}$ (see experimental details).

At first, monodentate ligand $\mathbf{4}$ and its corresponding boronated dyes, 5a-b were characterized (Table 2, Figures S40 and S41). The pure ligand 4 displayed two reversible oxidation 
waves at $+0.6 \mathrm{~V}$ and $+0.8 \mathrm{~V}$ which could be assigned to ICZ radical cation and di-cation, respectively. No reduction wave was observed in the electrochemical window accessible from DCM solution. The dye 5a exhibited two oxidation waves at $+0.8 \mathrm{~V}$ and $+1.15 \mathrm{~V}$ which were shifted towards higher anodic potential with respect to that of 4 . As expected, the oxidation processes became more difficult after coordination of the $\mathrm{BF}_{2}$ unit with 4 . Also, a single and nonreversible reduction wave was observed at $-1.4 \mathrm{~V}$ for $\mathbf{5 a}$. Interestingly, replacement of the Fluorine atoms by phenyl groups on the boron atoms of dye $\mathbf{5 a}$ allowed to tune its electrochemical properties. Thus, in case of dye $\mathbf{5 b}$, only the first reversible oxidation wave was observed at +0.65 $\mathrm{V}$, while the non-reversible reduction wave was measured at $-1.6 \mathrm{~V}$. Both the oxidation and reduction potentials were decreased by approximately $0.15 \mathrm{~V}$ as compared to the $\mathrm{BF}_{2}$ derivative 5a. Such behaviour is well known with the BODIPY dyes. ${ }^{45}$

Table 2. Electrochemical properties of $\mathbf{4}, \mathbf{5 a}-\mathbf{b}, \mathbf{7 a - b}, \mathbf{8}$ and 16 in DCM. ${ }^{\mathrm{a}}$

\begin{tabular}{cccccc}
\hline Compound & $\mathrm{Eox}^{\circ} / \mathrm{V}$ & $\mathrm{E}_{\mathrm{red}}{ }^{\circ} / \mathrm{V}$ & HOMO $(\mathrm{eV})^{\mathrm{b}}$ & LUMO $(\mathrm{eV})^{\mathrm{b}}$ & Band Gap $(\mathrm{eV})$ \\
\hline $\mathbf{4}$ & $+0.6 \mathrm{~V} ;+0.8 \mathrm{~V}$ & - & -5.00 & - & - \\
$\mathbf{5 a}$ & $+0.8 \mathrm{~V} ;+1.15 \mathrm{~V}$ & $-1.4 \mathrm{~V}$ irr & -5.20 & -3.00 & 2.2 \\
$\mathbf{5 b}$ & $+0.65 \mathrm{~V}$ & $-1.6 \mathrm{~V} \mathrm{irr}$ & -5.05 & -2.80 & 2.25 \\
$\mathbf{7 a}$ & $+0.8 \mathrm{~V} ;+0.9 \mathrm{~V}$ & $-0.95 \mathrm{~V}$ & -5.20 & -3.45 & 1.75 \\
$\mathbf{7 b}$ & $+0.7 \mathrm{~V} ;+0.75 \mathrm{~V}$ & $-1.1 \mathrm{~V}$ & -5.10 & -3.30 & 1.8 \\
$\mathbf{8}$ & $+0.8 \mathrm{~V} ;+1.1 \mathrm{~V}$ & & & -3.90 & 1.3 \\
$\mathbf{1 6}$ & (quasi-reversible) & $-0.5 \mathrm{~V}$ & -5.20 & -2.85 & 2.25
\end{tabular}

${ }^{\mathrm{a} C y c l i c}$ voltammetry was done in deoxygenated DCM containing TBAPF6 (0.1 M), and a solute concentration of $1-5 \times 10^{-3} \mathrm{M}$, at $25^{\circ} \mathrm{C}$. The error in half-wave potentials is $\pm 10 \mathrm{mV}$. ${ }^{\mathrm{b}} \mathrm{using}$ the formula $(\mathrm{HOMO}=\mathrm{Eox}+4.4 \mathrm{eV})$ and $\left(\mathrm{LUMO}=\mathrm{E}_{\mathrm{red}}+4.4 \mathrm{eV}\right)$ where the onset potentials are in volts (vs SCE) and HOMO and LUMO are in electron volts. ${ }^{46}$

Similar trend was also observed in the anti-ladder type complex series (Table 2, Figures S42 and S43). Indeed, a potential decrease of around 0.1-0.2 V was measured while going from the $\mathrm{BF}_{2}$ complex $\mathbf{7 a}$ to the $\mathrm{BPh}_{2}$ complex $\mathbf{7 b}$. Both the compounds exhibited two reversible oxidation waves at $+0.7 \mathrm{~V}$ and $+0.75 \mathrm{~V}$ for $7 \mathbf{b}$ against $+0.8 \mathrm{~V}$ and $+0.9 \mathrm{~V}$ for $7 \mathbf{a}$. In the cathodic 
region, a reversible wave for both compounds was recorded at $-1.1 \mathrm{~V}$ and $-0.95 \mathrm{~V}$ for $7 \mathbf{b}$ and $7 \mathbf{a}$, respectively. Due to the electron-poor nature of the two $\mathrm{BF}_{2}$ complexes, the symmetrical compound $\mathbf{8}$ exhibited a particular behaviour with two oxidation waves taking place at higher potentials, $+0.8 \mathrm{~V}$ (reversible) and $+1.1 \mathrm{~V}$ (quasi-reversible). The reversible reduction process of 8 was observed at a very low potential of $-0.5 \mathrm{~V}$, highlighting the strong electron affinity of this bis- $\mathrm{BF}_{2}$ complex.

Finally, the bis- $\mathrm{BF}_{2}$ dye 16, was compared with the mono- $\mathrm{BF}_{2} \mathbf{5}$ a complex (Table 2, Figures S44 and S45). In agreement with optical data, their electrochemical properties were also similar, highlighting the low conjugation extension of this symmetrical molecule. However, in cathodic region, a bi-electronic non-reversible reduction wave was observed which indicated that two independent radical anions were formed at a potential of approximately $-1.55 \mathrm{~V}$. A reversible oxidation wave was also recorded at $+0.7 \mathrm{~V}$. It obviously corresponds also to a bi-electronic oxidation process.

Interestingly, it can be noted that the electrochemical band-gaps (calculated as the difference between the LUMO and HOMO measured by CV: Table 2), are consistent with optical band-gaps measured from solid-state absorption onsets (Table 1). Further, the symmetrical compound $\mathbf{8}$ exhibits a significantly lower electrochemical band-gap compared to its monocomplex counterparts $\mathbf{7 a - b}$.

Thus, it is worth noting that the chemistry developed for the synthesis of various ICZ based boron complexes allows really the fine-tuning of photophysical and electrochemical properties of the dyes.

Theoretical calculations. Energetically favourable configurations of the ligand $\mathbf{4}$ and dyes $\mathbf{5 a}, \mathbf{5 b}$, $7 \mathbf{a}, 7 \mathbf{b}, 8$ and 16 were optimized to understand their geometry in the ground state and also to calculate and visualize their HOMO and LUMOs. This was done by density functional theory (DFT) calculations using B3LYP at the 6-31G* level in vacuum. All the pentyl side chains were changed to methyl groups in order to keep a reasonable calculation time and anticipating no influence of the aliphatic chains on the electronic structures of the dyes. 


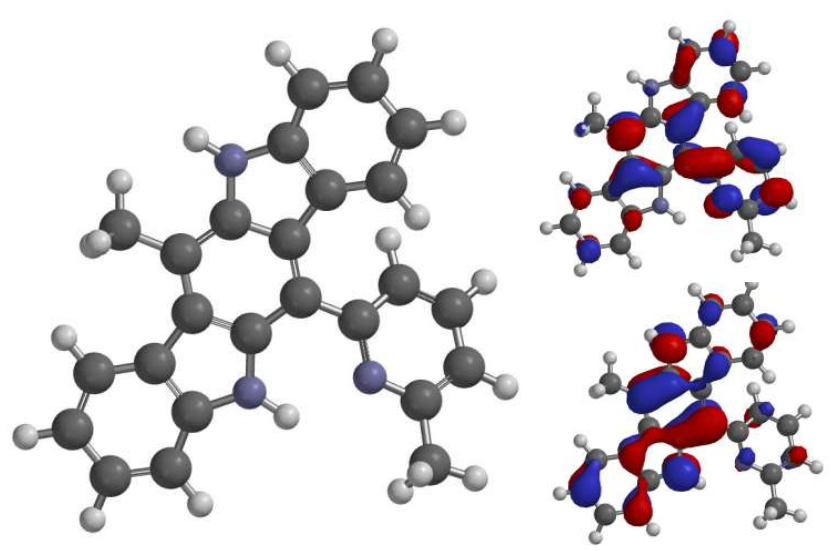

Figure 4. Optimized structure of 4 (left) and calculated LUMO (right-top) and HOMO (rightbottom) surfaces.

The optimized structure of $\mathbf{4}$ can be found in Figure 4 together with the calculated HOMO and LUMO surfaces. The pyridyl ring is out of the hypothetical plane containing the ICZ aromatic core with a calculated torsion angle of $-34^{\circ}$. The torsion angle leads to poorly delocalized HOMO and LUMO of 4 (Figure 4). The HOMO mainly spreads over the ICZ moiety while the LUMO is localized on the pyridyl moiety and centre phenyl ring of the ICZ moiety. The calculated frontier energy levels for the LUMO and HOMO are $-1.34 \mathrm{eV}$ and $-4.78 \mathrm{eV}$, respectively. The calculated HOMO is reasonably close to the one measured by $\mathrm{CV}(-5.0 \mathrm{eV})$ (Table 3$).{ }^{47}$
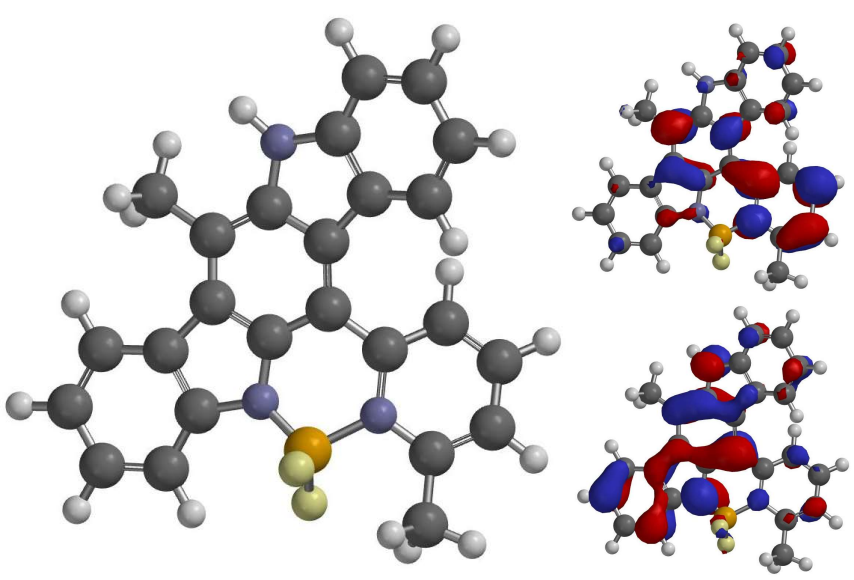

Figure 5. Optimized structure of 5a (left) and calculated LUMO (right-top) and HOMO (rightbottom) surfaces. 
The 5a optimized structure can be found in Figure 5 together with the calculated HOMO and LUMO surfaces. The optimized structure is in good agreement with the crystal structure measured by X-Ray, for instance a twist of the pyridyl ring which is out of the hypothetical plane containing the ICZ aromatic core with a calculated torsion angle $\mathrm{C} 17 / \mathrm{C} 6 / \mathrm{C} 6$ ' $/ \mathrm{C} 5^{\prime}$ of $-19.58^{\circ}$ instead of $-18.79^{\circ}$ as measured by X-Ray (the identification of the $\mathrm{C}$ atoms rely on the Ortep view in Figure 1). The torsion angle leads to poorly delocalized HOMO and LUMO of 5a (Figure 5). The HOMO spreads over the ICZ moiety while the LUMO is mainly centred on the pyridyl moiety. The calculated frontier energy levels for the LUMO and HOMO are $-2.02 \mathrm{eV}$ and $-4.95 \mathrm{eV}$, respectively. As usually observed for this type of calculations, the calculated HOMO is reasonably close to the one measured by CV ( $-4.95 \mathrm{eV}$ by DFT and $-5.2 \mathrm{eV}$ by CV) but the calculated LUMO $(-2.02 \mathrm{eV})$ lies almost $1.0 \mathrm{eV}$ above the $\mathrm{CV}$ measured one $(-3.0 \mathrm{eV}) .{ }^{47}$ The calculated HOMO and LUMO as well as the difference between calculated and measured frontier orbitals can be found in Table 3.

Table 3. Calculated HOMO (second column) and LUMO (fourth column) energy levels together with the offset between the measured (by CV) and the calculated (by DFT) HOMO (third column) and LUMO (fifth column) for $4,5 \mathbf{a}, 5 \mathbf{b}, 7 \mathbf{a}, 7 \mathbf{b}, 8$ and 16.

\begin{tabular}{ccccc}
\hline Dye & HOMO $_{\text {DFT }}(\mathrm{eV})$ & $\Delta_{\text {HOMO }}(\mathrm{eV})$ & LUMO $_{\text {DFT }}(\mathrm{eV})$ & $\Delta_{\text {LUMO }}(\mathrm{eV})$ \\
\hline $\mathbf{4}$ & -4.78 & 0.22 & -1.34 & - \\
$\mathbf{5 a}$ & -4.95 & 0.25 & -2.02 & 0.98 \\
$\mathbf{5 b}$ & -4.74 & 0.31 & -1.94 & 0.86 \\
$\mathbf{7 a}$ & -4.87 & 0.33 & -2.44 & 1.01 \\
$\mathbf{7 b}$ & -4.75 & 0.35 & -2.38 & 0.92 \\
$\mathbf{8}$ & -4.98 & 0.22 & -3.00 & 0.9 \\
$\mathbf{1 6}$ & -4.52 & 0.58 & -1.91 & 0.94 \\
\hline
\end{tabular}



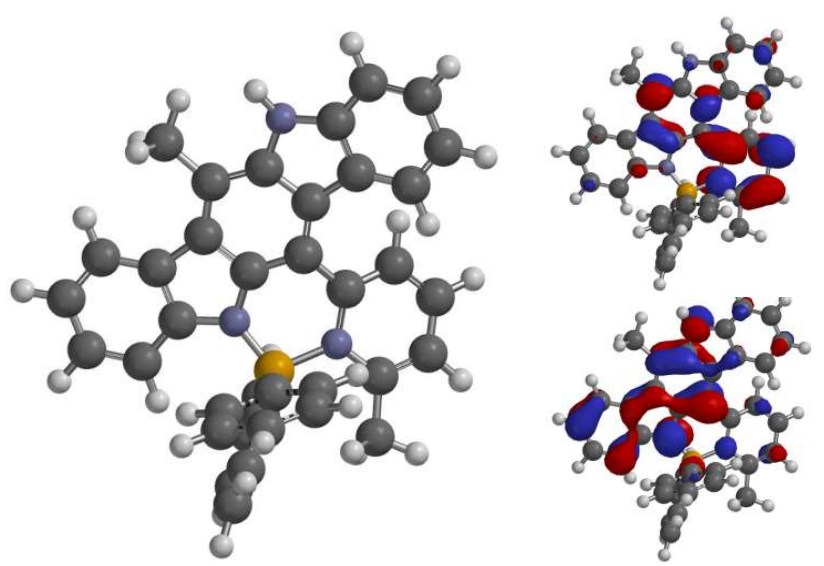

Figure 6. Optimized structure of $\mathbf{5 b}$ (left) and calculated LUMO (right-top) and HOMO (rightbottom) surfaces.

The $\mathbf{5 b}$ optimized structure can be found in Figure 6 together with the calculated HOMO and LUMO surfaces. The torsion angle between the ICZ and pyridyl planes slightly increases ($23^{\circ}$ ) as compared to 5a. Delocalization of the HOMO and LUMO remain similar to that of 5a. The calculated frontier energy levels for the LUMO and HOMO are $-1.94 \mathrm{eV}$ and $-4.74 \mathrm{eV}$, respectively. The general trend for the calculated frontier energy levels is in-line with the measured HOMO and LUMO values measured by CV (Table 3) with almost no change for the energy bandgap between 5a and $\mathbf{5 b}$ and frontier energy levels downshifted by 0.1 to $0.2 \mathrm{eV}$ when fluorine atoms are present on the dye (5a).

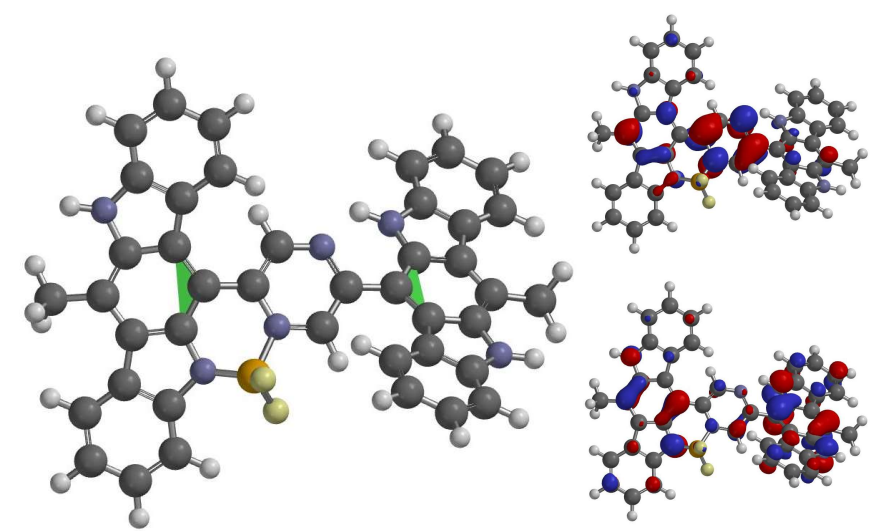

Figure 7. Optimized structure of 7a (left) and calculated LUMO (right-top) and HOMO (rightbottom) surfaces. 
The 7a optimized structure can be found in Figure 7 together with the calculated HOMO and LUMO surfaces. The torsion angle between the two planes containing the ICZ moieties (in green in Figure 7) is as high as $50^{\circ}$. Consequently, the extension of the LUMO is very limited as the LUMO is mainly confined to the pyrazine ring. Nevertheless, the LUMO delocalization is slightly more pronounced on the ICZ unit bridged to the pyrazine moiety by the $\mathrm{BF}_{2}$ group. Surprisingly, the HOMO is far less confined and it extends significantly over the two ICZ moieties. The general trend for the calculated frontier energy levels is in-line with the measured HOMO and LUMO values measured by CV (Table 3) with almost no change for the HOMO level between $\mathbf{5 a}$ and $\mathbf{7 a}$ but a much deeper LUMO level for $\mathbf{7 a}$ compared to $\mathbf{5 a}$.
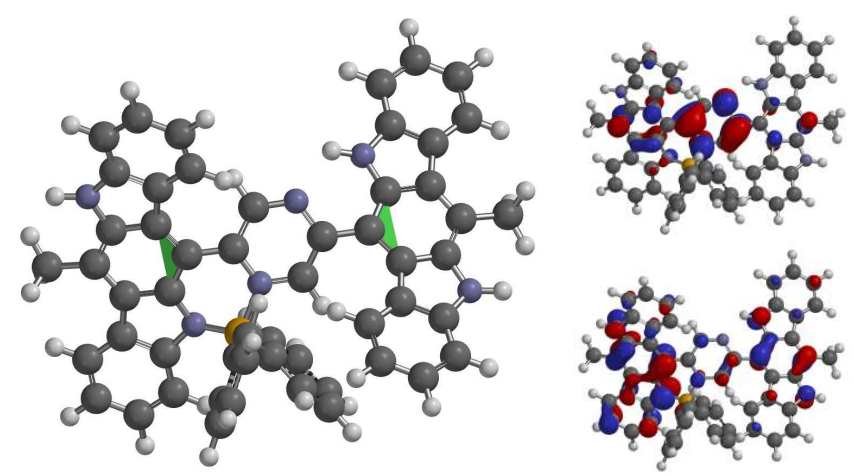

Figure 8. Optimized structure of $\mathbf{7 b}$ (left) and calculated LUMO (right-top) and HOMO (rightbottom) surfaces.

The optimized structure of $\mathbf{7 b}$ (Figure 8 ) shows that the torsion angle between the two planes containing the ICZ moieties (in green in Figure 8) increases $\left(56^{\circ}\right)$ as compared to $7 \mathbf{a}$. Delocalization of the HOMO and LUMO (Figure 8) remain similar to that of 7a. The calculated frontier energy levels for the LUMO and HOMO are $-2.38 \mathrm{eV}$ and $-4.75 \mathrm{eV}$, respectively (Table 3) i.e. the same trend is observed between $\mathbf{7 a}$ and $7 \mathbf{b}$ than between $\mathbf{5 a}$ and $\mathbf{5 b}$ with a downshifting of both frontier energy levels on the F-grafted dye compared to its phenyl-grafted counterpart. 

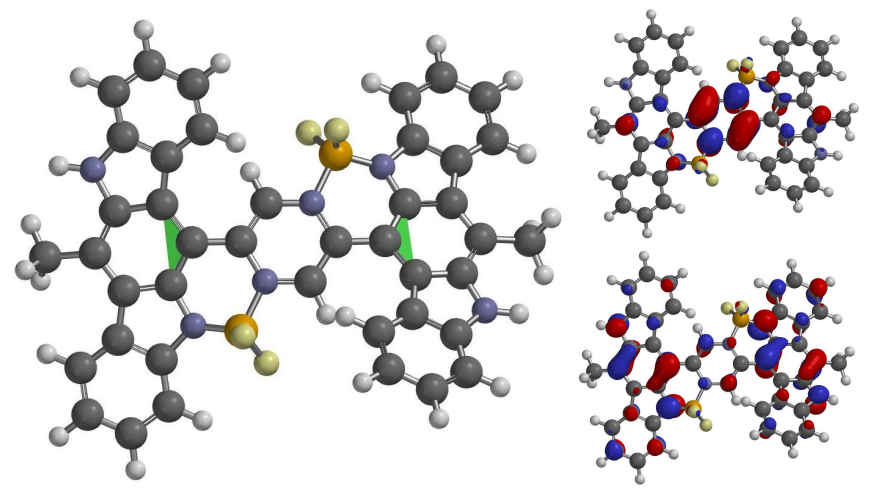

Figure 9. Optimized structure of $\mathbf{8}$ (left) and calculated LUMO (right-top) and HOMO (rightbottom) surfaces.

The optimized structure of $\mathbf{8}$ can be found in Figure 9 together with the calculated HOMO and LUMO surfaces. The torsion angle between the two planes containing the ICZ moieties (in green in Figure 9) is less than $38^{\circ}$ to be compared with the $50^{\circ}$ calculated for $7 \mathbf{a}$. Consequently, the HOMO and LUMO for $\mathbf{8}$ are much more extended than for $\mathbf{7 a}$. The HOMO is far less confined and it extends significantly over the two ICZ moieties. The general trend for the calculated frontier energy levels is in-line with the HOMO and LUMO values measured by CV (Table 3) with almost no change for the HOMO level between 5a, 7a and $\mathbf{8}$ but a significantly deeper LUMO level for $\mathbf{8}$ compared to $\mathbf{5 a}$ and 7a. Consequently, the calculated band-gap for $\mathbf{8}(1.98 \mathrm{eV})$ is almost $1 \mathrm{eV}$ lower than the calculated band-gap for $\mathbf{5 a}(2.93 \mathrm{eV})$. This calculated result is perfectly consistent with the $\mathrm{CV}$ measurements with a $0.9 \mathrm{eV}$ higher electrochemical gap for $\mathbf{5 a}(2.2 \mathrm{eV})$ compared to $8(1.3 \mathrm{eV})$.

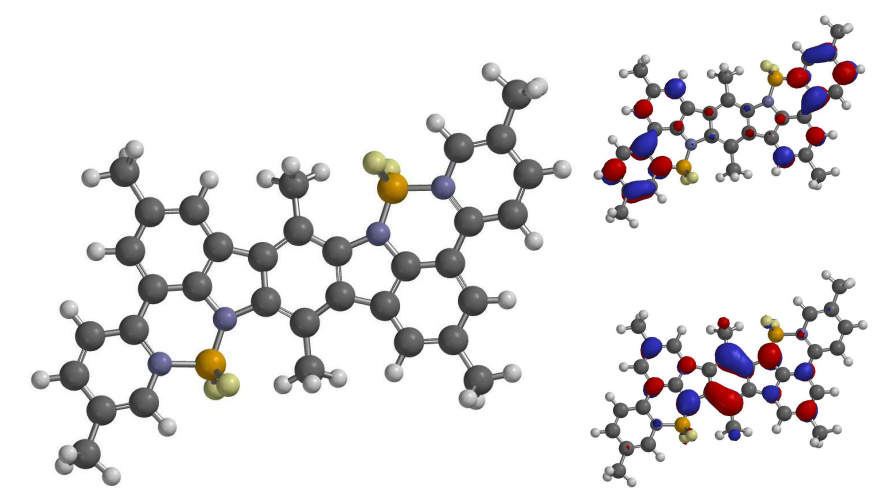

Figure 10. Optimized structure of $\mathbf{1 6}$ (left) and calculated LUMO (right-top) and HOMO (rightbottom) surfaces. 
The optimized structure of $\mathbf{1 6}$ can be found in Figure 10 together with the calculated HOMO and LUMO surfaces. The optimized structure is very planar in the case of $\mathbf{1 6}$ and the HOMO and LUMO are nicely delocalized over the dye. This very planar structure is in contradiction with the experimental evidences of a limited conjugation for this dye. The general trend for the calculated LUMO is in-line with the LUMO value measured by CV (Table 3). On the other hand, the calculated HOMO value for 16 is above the one calculated for $5 \mathbf{a}, 7 \mathbf{a}$ and $\mathbf{8}$ and seems too shallow compared to the measured one. Indeed, while the offset between the measured and calculated HOMO values is in the $0.6-0.7 \mathrm{eV}$ range for 5a, 7a and $\mathbf{8}$, it reaches $1 \mathrm{eV}$ for $\mathbf{1 6}$ (Table 3, third column). The weak conjugation of this dye, observed experimentally but not by simulation, impacts mainly the calculated HOMO value.

Conclusion: Thus, new synthetic strategies were developed for the functionalization of the ICZ moiety. Using these strategies three different types of pyridine-ICZ based APBD dyes and three anti-ladder-type $\pi$-conjugated dyes based on the pyrazine-ICZ structures were synthesized. Their detailed electrochemical and photophysical properties in solution, solid state and thin films were evaluated by cyclic voltammetry and optical spectroscopy, respectively. Interestingly, due to the high versatility of the developed chemical route, those properties can be tuned in a wide range. For instance, the absorption properties of those new boron-complexes cover most of the UV-visibleNIR spectrum, from 350 to $950 \mathrm{~nm}$ even in solution. As a consequence, this appealing tunability feature makes those new types of dyes very promising candidates for their further use in functional material development.

\section{Experimental Section:}

Experimental Details. All reactions were performed under argon atmosphere using standard Schlenk tube techniques. All the chemicals were used as received from commercial sources unless stated otherwise. DCM, THF and DMF were distilled from $\mathrm{P}_{2} \mathrm{O}_{5}$, sodium and benzophenone, and $\mathrm{KOH}$ respectively under an argon atmosphere. Chromatographic purifications were performed using silica gel $(40-63 \mu \mathrm{m})$. TLC was performed on silica gel plates coated with fluorescent indicator. The ${ }^{1} \mathrm{H}$ and ${ }^{13} \mathrm{C}$ spectra were recorded at room temperature with a $300 \mathrm{MHz}$ or $400 \mathrm{MHz}$ spectrometer, using perdeuterated solvents as the internal standards. The ${ }^{1} \mathrm{H}$ and ${ }^{13} \mathrm{C}$ chemical shifts are given in ppm relative to the residual protiated solvent or the solvent, respectively. The 
FT-IR spectra were recorded as thin solid layers using an apparatus equipped with an ATR "diamond" apparatus. Absorption spectra were recorded on a Schimadzu UV-2600 absorption spectrometer. Absorption in the solid state was done on thin film of neat compound prepared by spin-coating. The steady-state emission and excitation spectra were recorded with a spectrofluorimeter (Fluoromax-4 Horiba Jobin Yvon). All fluorescence spectra were corrected. The following equation was used to determine the relative fluorescence quantum yield:

$\phi(\mathrm{X})=\left(\mathrm{A}_{\mathrm{S}} / \mathrm{Ax}_{\mathrm{X}}\right)\left(\mathrm{F}_{\mathrm{X}} / \mathrm{F}_{\mathrm{S}}\right)\left(\mathrm{n}_{\mathrm{X}} / \mathrm{n}_{\mathrm{S}}\right)^{2} \phi(\mathrm{S})$

Where $\mathrm{A}$ is the absorbance at the excitation wavelength (in the range 0.01-0.1 A.U.), F is the area under the corrected emission curve, $\mathrm{n}$ is the refractive index of the solvents (at $25^{\circ} \mathrm{C}$ ) used in measurements, and the subscripts $\mathrm{S}$ and $\mathrm{X}$ represent standard and unknown, respectively. Fluorescence quantum yields $\left(\Phi_{\mathrm{fl}}\right)$ were determined using Rhodamine $6 \mathrm{G}$ in ethanol $\left(\Phi_{\mathrm{fl}}=0.88\right)$ as the reference. ${ }^{40}$ Solid state fluorescence spectra were recorded with $\mathrm{KBr}$ pellets of desired compound at $10^{-6} \mathrm{M}$ concentration. $\mathrm{KBr}$ pellets were made after proper grinding of the desired compounds with the dry $\mathrm{KBr}$. The quantum yields were determined with an integration sphere using the $\mathrm{KBr}$ pellets.

Oxidation and reduction potentials were determined by cyclic voltammetry with a conventional 3-electrode system using a voltammetric analyzer equipped with a platinum micro disk $\left(2 \mathrm{~mm}^{2}\right)$ working electrode and a platinum wire counter electrode. The reference electrode is constituted of a non-aqueous silver electrode including the following electrolyte solution: $0.01 \mathrm{M}$ silver nitrate $+0.1 \mathrm{M}$ Tetrabutylammonium perchlorate in Acetonitrile. Potentials were calibrated versus the saturated calomel electrode (SCE), using the ferrocene/ferrocinium $\left(F c / F c^{+}\right)$couple as an internal reference and a conventional scan rate of $150 \mathrm{mV} / \mathrm{s}$. Recrystallized tetrabutylammonium hexafluorophosphate $\left(\mathrm{Bu}_{4} \mathrm{NPF}_{6}\right)$ was used as the supporting electrolyte $(0.1$ $\mathrm{M})$ in distilled and anhydrous DCM. All potentials are referred to the SCE electrode that was

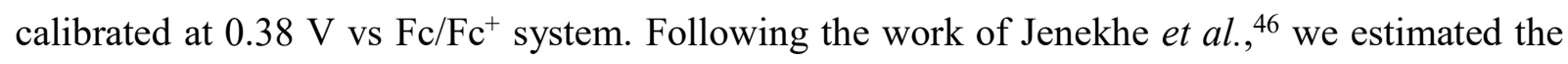
electron affinity (EA) or lowest unoccupied molecular orbital (LUMO) and the ionization potential (IP) or highest occupied molecular orbital (HOMO) from the redox data. The LUMO and HOMO levels were calculated from the following equations, using the oxidation and reduction onset potentials: $\mathrm{LUMO}(\mathrm{eV})=-\left[\mathrm{E}_{\text {onsetred }}(\mathrm{vs} \mathrm{SCE})+4.4\right]$ and $\mathrm{HOMO}(\mathrm{eV})=-\left[\mathrm{E}_{\text {onsetOx }}(\mathrm{vs} \mathrm{SCE})+\right.$ 4.4 , based on an SCE energy level of $4.4 \mathrm{eV}$ relative to the vacuum. 


\section{Synthetic Details.}

\section{General Procedure for the Synthesis of 6-Pentyl-5,11-dihydroindolo[3,2-b] carbazoles (1/9):}

To a mixture of indole (for 1)/5-bromoindole (for 9) $(9.2 \mathrm{mmol})$ and hexanal $(0.56 \mathrm{~mL}, 4.6 \mathrm{mmol})$ in $\mathrm{CH}_{3} \mathrm{CN}(15 \mathrm{~mL}), \mathrm{I}_{2}(233.0 \mathrm{mg}, 0.92 \mathrm{mmol})$ was added, and the reaction mixture was allowed to stir at $25{ }^{\circ} \mathrm{C}$ for $14 \mathrm{~h}$. The reaction was quenched with saturated aq. $\mathrm{Na}_{2} \mathrm{SO}_{3}(50 \mathrm{~mL})$ and the solution was extracted with EtOAc $\left(30 \mathrm{~mL} \mathrm{X} \mathrm{3).} \mathrm{The} \mathrm{organic} \mathrm{layer} \mathrm{was} \mathrm{washed} \mathrm{with} \mathrm{H}_{2} \mathrm{O}(50 \mathrm{~mL}\right.$ X 3) and dried over anhydrous $\mathrm{Na}_{2} \mathrm{SO}_{4}$. After removal of the solvent under vacuum, the crude product dissolved in $\mathrm{MeOH}(6 \mathrm{~mL})$. Then triethyl orthoformate $(0.76 \mathrm{~mL}, 4.6 \mathrm{mmol})$ and methanesulfonic acid $(60.0 \mu \mathrm{L}, 0.92 \mathrm{mmol})$ were added to it, and the reaction mixture was stirred overnight at $25^{\circ} \mathrm{C}$. The precipitate formed was filtered off, washed with $\mathrm{MeOH}$ and dried under vacuum to get yellowish compounds $\mathbf{1 / 9}$.

Compound $1^{38}$. Yield: $1.26 \mathrm{~g}(42 \%) ;{ }^{1} \mathrm{H}$ NMR (400 MHz, $\left.\left(\mathrm{CD}_{3}\right)_{2} \mathrm{CO}, 25^{\circ} \mathrm{C}, \mathrm{TMS}\right): \delta 0.92(\mathrm{t}, J=$ $7.2 \mathrm{~Hz}, 3 \mathrm{H}), 1.38-1.48(\mathrm{~m}, 2 \mathrm{H}), 1.59-1.67(\mathrm{~m}, 2 \mathrm{H}), 1.91-1.98(\mathrm{~m}, 2 \mathrm{H}), 3.58(\mathrm{t}, J=8.0 \mathrm{~Hz}, 2 \mathrm{H})$, 7.13 (t, $J=7.2 \mathrm{~Hz}, 1 \mathrm{H}), 7.18(\mathrm{t}, J=7.2 \mathrm{~Hz}, 1 \mathrm{H}), 7.34-7.39$ (m, 2H), 7.47-7.52 (m, 2H), 8.03 (s, $1 \mathrm{H}), 8.13(\mathrm{~d}, J=7.6 \mathrm{~Hz}, 1 \mathrm{H}), 8.20(\mathrm{~d}, J=8.0 \mathrm{~Hz}, 1 \mathrm{H}), 10.15(\mathrm{~s}, 1 \mathrm{H}), 10.19(\mathrm{~s}, 1 \mathrm{H}) ;{ }^{13} \mathrm{C}\left\{{ }^{1} \mathrm{H}\right\} \mathrm{NMR}$ (75 MHz, DMSO-d $\left.\mathrm{d}_{6}, 25^{\circ} \mathrm{C}, \mathrm{TMS}\right): \delta 13.9,22.3,28.3,28.7,31.6,97.9,110.3,110.6,117.5,117.7$, $118.2,120.1,120.2,121.7,122.2,122.5,122.8,124.7,125.3,134.0,135.6,141.2$.

Compound 9 ${ }^{38}$. Yield: $978 \mathrm{mg}(22 \%) ;{ }^{1} \mathrm{H}$ NMR (400 MHz, DMSO-d $\left.6,25{ }^{\circ} \mathrm{C}, \mathrm{TMS}\right): \delta 0.90$ (t, $J$ $=7.3 \mathrm{~Hz}, 3 \mathrm{H}), 1.37-1.46(\mathrm{~m}, 2 \mathrm{H}), 1.52-1.59(\mathrm{~m}, 2 \mathrm{H}), 1.76-1.84(\mathrm{~m}, 2 \mathrm{H}), 3.43(\mathrm{t}, J=7.8 \mathrm{~Hz}, 2 \mathrm{H})$, 7.44-7.53 (m, 4H), 8.07 (s, 1H), 8.19 (d, $J=1.6 \mathrm{~Hz}, 1 \mathrm{H}), 8.45$ (d, $J=1.9 \mathrm{~Hz}, 1 \mathrm{H}), 11.17(\mathrm{~s}, 1 \mathrm{H})$, $11.37(\mathrm{~s}, 1 \mathrm{H}) ;{ }^{13} \mathrm{C}\left\{{ }^{1} \mathrm{H}\right\}$ NMR (75 MHz, DMSO-d $\left.6,25{ }^{\circ} \mathrm{C}, \mathrm{TMS}\right): \delta 13.9,22.0,28.1,28.3,31.5$, 98.8, 109.5, 109.6, 112.3, 112.5, 118.6, 119.6, 121.9, 122.9, 124.0, 124.1, 124.7, 127.3, 127.9, 134.4, 136.0, 139.9, 140.0. MS (m/z): $405.0[\mathrm{M}+\mathrm{H}]^{+}$; Anal. calcd. for $\mathrm{C}_{23} \mathrm{H}_{20} \mathrm{Br}_{2} \mathrm{~N}_{2}: \mathrm{C}, 57.05 ; \mathrm{H}$, 4.16; N, 5.79\%. Found: C, 57.38; H, 4.38; N, 5.57\%.

Compound $2^{38}$. To a solution of $1(400 \mathrm{mg}, 1.23 \mathrm{mmol})$ in $\mathrm{THF} / \mathrm{H}_{2} \mathrm{O}(5: 2,28 \mathrm{~mL})$, anhydrous $\mathrm{FeBr}_{3}(1.09 \mathrm{~g}, 3.68 \mathrm{mmol})$ was added and the mixture was stirred at $25^{\circ} \mathrm{C}$ for $20 \mathrm{~h} . \mathrm{H}_{2} \mathrm{O}(20 \mathrm{~mL})$ was added to it and the solution was extracted with EtOAc $(30 \mathrm{~mL} \mathrm{X} \mathrm{3).} \mathrm{The} \mathrm{organic} \mathrm{layer} \mathrm{was}$ washed with $\mathrm{H}_{2} \mathrm{O}(50 \mathrm{~mL} X 3)$ and dried over anhydrous $\mathrm{Na}_{2} \mathrm{SO}_{4}$. After removal of solvents under vacuum, the crude product was purified by column chromatography (silica gel, EtOAc/petroleum 
ether, 25:75) to furnish 2 (427 mg, 86\%) as a white solid. ${ }^{1} \mathrm{H}$ NMR (400 MHz, DMSO-d $6,25{ }^{\circ} \mathrm{C}$, TMS): $\delta 0.88(\mathrm{t}, J=7.2 \mathrm{~Hz}, 3 \mathrm{H}), 1.33-1.42(\mathrm{~m}, 2 \mathrm{H}), 1.52-1.59(\mathrm{~m}, 2 \mathrm{H}), 1.77-1.85(\mathrm{~m}, 2 \mathrm{H}), 3.49$ $(\mathrm{t}, J=7.6 \mathrm{~Hz}, 2 \mathrm{H}), 7.18-7.23(\mathrm{~m}, 2 \mathrm{H}), 7.41-7.48(\mathrm{~m}, 2 \mathrm{H}), 7.55-7.61(\mathrm{~m}, 2 \mathrm{H}), 8.12(\mathrm{~d}, J=8.0 \mathrm{~Hz}$, 1H), $8.67(\mathrm{~d}, J=7.8 \mathrm{~Hz}, 1 \mathrm{H}), 11.13(\mathrm{~s}, 1 \mathrm{H}), 11.25(\mathrm{~s}, 1 \mathrm{H}) ;{ }^{13} \mathrm{C}\left\{{ }^{1} \mathrm{H}\right\}$ NMR $\left(75 \mathrm{MHz}, \mathrm{DMSO}-\mathrm{d}_{6}\right.$, $25{ }^{\circ} \mathrm{C}$, TMS): $\delta$ 14.4, 22.6, 28.4, 29.1, 31.9, 93.2, 111.2, 111.6, 118.1, 118.3, 119.0, 119.8, 121.1, 121.9, 122.5, 123.1, 125.8, 126.3, 134.4, 135.0, 141.6. MS (m/z): $405.0[\mathrm{M}+\mathrm{H}]^{+}$; Anal. calcd. for $\mathrm{C}_{23} \mathrm{H}_{21} \mathrm{BrN}_{2}$ : C, 68.15; H, 5.22; N, 6.91\%. Found: C, 68.06; H, 5.26; N, 6.73\%.

Compound 3: A solution of $2(330.0 \mathrm{mg}, 0.81 \mathrm{mmol})$ in 1,4-dioxane $(15 \mathrm{~mL})$ in a Schlenk flask was purged with argon and then charged with pinacolborane $(0.6 \mathrm{~mL}, 4.1 \mathrm{mmol}), \mathrm{Et}_{3} \mathrm{~N}(1.23 \mathrm{~mL})$ and $\mathrm{Pd}\left(\mathrm{PPh}_{3}\right)_{2} \mathrm{Cl}_{2}(57.0 \mathrm{mg}, 0.08 \mathrm{mmol})$ respectively. The mixture was stirred at reflux for $12 \mathrm{~h}$ under argon. After removal of solvents under vacuum, the crude product was purified by column chromatography (silica gel, DCM/petroleum ether, 25:75) to furnish 3 (250 $\mathrm{mg}, 80 \%)$ as a yellowish solid. ${ }^{1} \mathrm{H}$ NMR (300 MHz, DMSO-d $\left.6,25{ }^{\circ} \mathrm{C}, \mathrm{TMS}\right): \delta 0.88$ (t, $\left.J=7.2 \mathrm{~Hz}, 3 \mathrm{H}\right), 1.32-$ $1.44(\mathrm{~m}, 2 \mathrm{H}), 1.53-1.62(\mathrm{~m}, 14 \mathrm{H}), 1.76-1.87(\mathrm{~m}, 2 \mathrm{H}), 3.54(\mathrm{t}, J=7.5 \mathrm{~Hz}, 2 \mathrm{H}), 7.10$ (t, $J=7.2 \mathrm{~Hz}$, $1 \mathrm{H}), 7.19(\mathrm{t}, J=7.2 \mathrm{~Hz}, 1 \mathrm{H}), 7.35-7.43(\mathrm{~m}, 2 \mathrm{H}), 7.50(\mathrm{~d}, J=8.4 \mathrm{~Hz}, 1 \mathrm{H}), 7.74(\mathrm{~d}, J=7.8 \mathrm{~Hz}, 1 \mathrm{H})$, $8.12(\mathrm{~d}, J=7.8 \mathrm{~Hz}, 1 \mathrm{H}), 9.05(\mathrm{~d}, J=8.1 \mathrm{~Hz}, 1 \mathrm{H}), 10.14(\mathrm{~s}, 1 \mathrm{H}), 11.07(\mathrm{~s}, 1 \mathrm{H}) ;{ }^{13} \mathrm{C}\left\{{ }^{1} \mathrm{H}\right\} \mathrm{NMR}(75$ MHz, DMSO-d $\left.6,2{ }^{\circ} \mathrm{C}, \mathrm{TMS}\right): \delta$ 14.0, 22.3, 24.8, 28.4, 28.6, 31.6, 83.7, 110.4, 111.1, 117.3, 118.2, 119.1, 121.7, 121.8, 122.9, 123.5, 124.2, 124.9, 125.4, 126.0, 133.9, 140.6, 141.4, 142.3; MS (m/z): $452.2[\mathrm{M}]^{+}$; Anal. calcd. for $\mathrm{C}_{29} \mathrm{H}_{33} \mathrm{BN}_{2} \mathrm{O}_{2}: \mathrm{C}, 76.99 ; \mathrm{H}, 7.35 ; \mathrm{N}, 6.19 \%$. Found: C, $76.67 ; \mathrm{H}, 7.28 ; \mathrm{N}, 6.10 \%$.

\section{General Procedure for the Ligand Synthesis by Suzuki-Miyaura Coupling Reaction: A} mixture of 3/15, corresponding 2-bromopyridine/2,5-dibromopyrrazine, $\mathrm{Pd}\left(\mathrm{PPh}_{3}\right)_{4}, \mathrm{Cs}_{2} \mathrm{CO}_{3}$ and $\mathrm{CsF}$ and, dry toluene and DMF (2/1, v/v) in a Schlenk flask was degassed thoroughly and then stirred at $90{ }^{\circ} \mathrm{C}$ for $12 \mathrm{~h}$ under argon. The reaction was quenched with water, and the mixture was extracted with DCM. The organic layer was dried over anhydrous sodium sulfate. After removal of solvents under vacuum, the crude product was purified by column chromatography to afford the desired product. 
Compound 4. Ligand 4 was prepared by the Suzuki-Miyaura coupling reaction of $\mathbf{3}(200 \mathrm{mg}, 0.5$ mmol) with 2-bromo-5-methylpyridine $(27.0 \mathrm{mg}, 1.6 \mathrm{mmol})$ in presence of $\mathrm{Pd}\left(\mathrm{PPh}_{3}\right)_{4}(15 \mathrm{mg}, 0.01$ $\mathrm{mmol}), \mathrm{Cs}_{2} \mathrm{CO}_{3}(102 \mathrm{mg}, 0.3 \mathrm{mmol})$ and $\mathrm{CsF}(48 \mathrm{mg}, 0.3 \mathrm{mmol})$ in $6 \mathrm{~mL}$ toluene and DMF (2/1, $\mathrm{v} / \mathrm{v}$ ) according to the general procedure. Crude product was purified by column chromatography (silica gel, DCM/petroleum ether, 50:50) to furnish pure 4 (175 $\mathrm{mg}, 80 \%$ ) as a yellow solid. Mp: $190.2{ }^{\circ} \mathrm{C}$; IR (neat, $\mathrm{cm}^{-1}$ ): 3414, 2924, 2863, 1688, 1571, 1531, 1455, 1313, 740; ${ }^{1} \mathrm{H}$ NMR (400 $\left.\mathrm{MHz},\left(\mathrm{CD}_{3}\right)_{2} \mathrm{CO}, 25{ }^{\circ} \mathrm{C}, \mathrm{TMS}\right): \delta 0.94(\mathrm{t}, J=7.2 \mathrm{~Hz}, 3 \mathrm{H}), 1.41-1.50(\mathrm{~m}, 2 \mathrm{H}), 1.63-1.70(\mathrm{~m}, 2 \mathrm{H})$, 1.95-2.01 (m, 2H), $2.69(\mathrm{~s}, 3 \mathrm{H}), 3.64(\mathrm{t}, J=8.0 \mathrm{~Hz}, 2 \mathrm{H}), 6.91(\mathrm{t}, J=7.2 \mathrm{~Hz}, 1 \mathrm{H}), 7.19$ (t, $J=7.2$ $\mathrm{Hz}, 1 \mathrm{H}), 7.30-7.39(\mathrm{~m}, 3 \mathrm{H}), 7.50(\mathrm{~d}, J=8.0 \mathrm{~Hz}, 2 \mathrm{H}), 7.64(\mathrm{~d}, J=8.0 \mathrm{~Hz}, 1 \mathrm{H}), 7.75(\mathrm{~d}, J=7.6 \mathrm{~Hz}$, $1 \mathrm{H}), 7.91(\mathrm{t}, J=8.0 \mathrm{~Hz}, 1 \mathrm{H}), 8.24(\mathrm{~d}, J=8.0 \mathrm{~Hz}, 1 \mathrm{H}), 10.21(\mathrm{~s}, 1 \mathrm{H}) 10.35(\mathrm{~s}, 1 \mathrm{H}) ;{ }^{13} \mathrm{C}\left\{{ }^{1} \mathrm{H}\right\} \mathrm{NMR}$ (75 MHz, $\left(\mathrm{CD}_{3}\right)_{2} \mathrm{CO}, 25{ }^{\circ} \mathrm{C}$, TMS): $\delta 14.5,23.5,24.8,33.0,111.5,111.6,115.4,118.3,119.1$, 120.0, 120.4, 121.8, 122.3, 123.0, 123.1, 123.5, 123.7, 123.9, 125.9, 126.2, 135.6, 135.8, 137.7, 142.6, 142.7, 157.3, 159.6; HRMS (ESI-TOF) m/z: $[\mathrm{M}+\mathrm{H}]^{+}$Calcd. for $\mathrm{C}_{29} \mathrm{H}_{27} \mathrm{~N}_{3}$ : 418.5640; Found: 418.5254; Anal. calcd. for $\mathrm{C}_{29} \mathrm{H}_{27} \mathrm{~N}_{3}$ : C, 83.42; H, 6.52; N, 10.06\%. Found: C, 83.13; H, $6.45 ; \mathrm{N}, 9.79 \%$.

Compound 6. Ligand 6 was prepared by the Suzuki-Miyaura coupling reaction of $3(140 \mathrm{mg}$, $0.31 \mathrm{mmol}$ ) with 2,5-dibromopyrazine $(33.0 \mathrm{mg}, 0.45 \mathrm{mmol})$ in presence of $\mathrm{Pd}\left(\mathrm{PPh}_{3}\right)_{4}(36 \mathrm{mg}$, $0.03 \mathrm{mmol}), \mathrm{Cs}_{2} \mathrm{CO}_{3}(326 \mathrm{mg}, 0.74 \mathrm{mmol})$ and $\mathrm{CsF}(113 \mathrm{mg}, 0.74 \mathrm{mmol})$ in $12 \mathrm{~mL}$ toluene and DMF $(2 / 1, v / v)$ according to the general procedure. Crude product was purified by column chromatography (silica gel, DCM/petroleum ether, 40:60) to furnish pure 6 (70 $\mathrm{mg}, 69 \%$ ) as a yellow solid. Mp: $294.3{ }^{\circ} \mathrm{C}$; IR (neat, $\mathrm{cm}^{-1}$ ): 3457, 2860, 1607, 1530, 1463, 1318, 741; ${ }^{1} \mathrm{H}$ NMR (400 MHz, DMSO-d $\left.6,25^{\circ} \mathrm{C}, \mathrm{TMS}\right): \delta 0.94$ (t, $\left.J=7.2 \mathrm{~Hz}, 6 \mathrm{H}\right), 1.41-1.50(\mathrm{~m}, 4 \mathrm{H}), 1.62-1.70$ (m, $4 \mathrm{H}), 1.90-1.97(\mathrm{~m}, 4 \mathrm{H}), 3.63(\mathrm{t}, J=7.6 \mathrm{~Hz}, 4 \mathrm{H}), 6.95-6.99(\mathrm{~m}, 2 \mathrm{H}), 7.22-7.26(\mathrm{~m}, 2 \mathrm{H}), 7.38-7.45$ (m, 4H), 7.59 (d, $J=8.0 \mathrm{~Hz}, 4 \mathrm{H}), 7.67$ (d, $J=8.0 \mathrm{~Hz}, 2 \mathrm{H}), 8.22$ (d, $J=8.4 \mathrm{~Hz}, 2 \mathrm{H}), 9.42(\mathrm{~s}, 2 \mathrm{H})$, 10.97 (s, 1H), $11.30(\mathrm{~s}, 2 \mathrm{H}) ;{ }^{13} \mathrm{C}\left\{{ }^{1} \mathrm{H}\right\}$ NMR $\left(75 \mathrm{MHz},\left(\mathrm{CD}_{3}\right)_{2} \mathrm{CO}, 25{ }^{\circ} \mathrm{C}, \mathrm{TMS}\right): \delta 14.5,23.6,29.1$, 33.1, 111.4, 111.8, 112.0, 118.8, 119.6, 120.6, 121.8, 122.2, 123.1, 123.2, 123.5, 123.9, 126.3, 126.7, 135.9, 136.4, 142.7, 142.8, 146.8, 151.4; HRMS (ESI-TOF) m/z: [M] $]^{+}$Calcd. for $\mathrm{C}_{50} \mathrm{H}_{44} \mathrm{~N}_{6}$ : 728.3627; Found: 728.3573. Anal. calcd. for $\mathrm{C}_{50} \mathrm{H}_{44} \mathrm{~N}_{6}$; C, 82.39; H, 6.08; N, 11.53\%. Found: C, 82.07; H, 6.24; N, 11.37\%. 
General Procedure for the Synthesis of $\mathbf{B F}_{2}$-complexes $(5 \mathbf{a} / 7 \mathbf{a} / 8)$. In a solution of the ligand $(4 / 6)$ in DCE was added trimethylamine $\left(\mathrm{Et}_{3} \mathrm{~N}\right)$ and the mixture was stirred at $25{ }^{\circ} \mathrm{C}$ for 15 min. $\mathrm{BF}_{3} \cdot \mathrm{OEt}_{2}$ was added dropwise into it and the reaction mixture was stirred at $80{ }^{\circ} \mathrm{C}$ for $12 \mathrm{~h}$ (for $\mathbf{5 a}$ and $7 \mathbf{a}$ ) $/ 48 \mathrm{~h}$ (for 8) under argon and then cooled to room temperature. The reaction was quenched with aq. $\mathrm{NaHCO}_{3}$, extracted with DCM. The organic layer was washed with $\mathrm{H}_{2} \mathrm{O}(50 \mathrm{~mL}$ X 3) and dried over anhydrous $\mathrm{Na}_{2} \mathrm{SO}_{4}$. After removal of the solvent under vacuum, the residue was purified by column chromatography on silica gel to afford the desired product.

Compound 5a. Dye 5a was prepared by reaction of $4(230 \mathrm{mg}, 0.55 \mathrm{mmol}), \mathrm{Et}_{3} \mathrm{~N}(0.23 \mathrm{~mL}, 1.65$ $\mathrm{mmol})$ and $\mathrm{BF}_{3} \cdot \mathrm{OEt}_{2}(0.21 \mathrm{~mL}, 1.65 \mathrm{mmol})$ in $20 \mathrm{~mL}$ DCE according to the general procedure. Crude product was purified by column chromatography (silica gel, DCM/petroleum ether, 50:50) to furnish pure $\mathbf{5 a}(230 \mathrm{mg}, 90 \%)$ as orange solid. Mp: $207.0^{\circ} \mathrm{C}$; IR (neat, $\left.\mathrm{cm}^{-1}\right)$ : 3419, 2952, 1610, 1550, 1516, 1461, 1255, 736; ${ }^{1} \mathrm{H}$ NMR (400 MHz, $\left.\left(\mathrm{CD}_{3}\right)_{2} \mathrm{CO}, 25{ }^{\circ} \mathrm{C}, \mathrm{TMS}\right): \delta 0.92(\mathrm{t}, J=7.2 \mathrm{~Hz}$, $3 \mathrm{H}), 1.40-1.49(\mathrm{~m}, 2 \mathrm{H}), 1.62-1.70(\mathrm{~m}, 14 \mathrm{H}), 1.96-2.03(\mathrm{~m}, 2 \mathrm{H}), 3.16(\mathrm{t}, J=3.2 \mathrm{~Hz}, 3 \mathrm{H}), 3.68(\mathrm{t}, J$ $=8.0 \mathrm{~Hz}, 2 \mathrm{H}), 7.13-7.17(\mathrm{~m}, 1 \mathrm{H}), 7.27-7.31(\mathrm{~m}, 1 \mathrm{H}), 7.43-7.51(\mathrm{~m}, 2 \mathrm{H}), 7.63(\mathrm{~d}, J=8.4 \mathrm{~Hz}, 1 \mathrm{H})$, $7.68(\mathrm{~d}, J=7.2 \mathrm{~Hz}, 1 \mathrm{H}), 7.93(\mathrm{~d}, J=8.0 \mathrm{~Hz}, 1 \mathrm{H}), 8.25(\mathrm{~d}, J=8.0 \mathrm{~Hz}, 1 \mathrm{H}), 8.34-8.38(\mathrm{~m}, 2 \mathrm{H}), 8.92$ $(\mathrm{d}, J=8.0 \mathrm{~Hz}, 1 \mathrm{H}), 10.84(\mathrm{~s}, 1 \mathrm{H}) ;{ }^{13} \mathrm{C}\left\{{ }^{1} \mathrm{H}\right\} \mathrm{NMR}\left(75 \mathrm{MHz},\left(\mathrm{CD}_{3}\right)_{2} \mathrm{CO}, 25{ }^{\circ} \mathrm{C}, \mathrm{TMS}\right): \delta 14.4,23.0$, 23.2, 23.5, 27.5, 33.0, 104.8, 112.6, 114.5, 118.2, 118.8, 120.6, 122.1, 122.6, 123.2, 123.6, 124.6, $125.4,125.7,126.6,126.9,127.5,136.5,141.4,142.5,145.2,152.1,157.2,158.8 ; \mathrm{MS}$ (m/z): 465.1 $[\mathrm{M}]^{+}$; HRMS (ESI-TOF) m/z: [M] ${ }^{+}$Calcd. for $\mathrm{C}_{29} \mathrm{H}_{26} \mathrm{BF}_{2} \mathrm{~N}_{3}$ : 465.2188; Found: 465.2216.

Compound 7a. Dye 7a was prepared by reaction of 6 (150 mg, $0.21 \mathrm{mmol}), \mathrm{Et}_{3} \mathrm{~N}(71 \mu \mathrm{L}, 0.20$ $\mathrm{mmol})$ and $\mathrm{BF}_{3} \cdot \mathrm{OEt}_{2}(25 \mu \mathrm{L}, 0.20 \mathrm{mmol})$ in $15 \mathrm{~mL} \mathrm{DCE}$ according to the general procedure. Crude product was purified by column chromatography (silica gel, DCM/petroleum ether, 50:50) to furnish pure 7a (115 mg, 72\%) as blue solid. Mp: $210.0{ }^{\circ} \mathrm{C}$; IR (neat, $\mathrm{cm}^{-1}$ ): 3431, 2919, 1664, 1578, 1515, 1318, 740; ${ }^{1} \mathrm{H}$ NMR (400 MHz, DMSO-d $6,25{ }^{\circ} \mathrm{C}$, TMS): $\delta$ 0.90-0.95 (m, 6H), 1.41 $1.47(\mathrm{~m}, 4 \mathrm{H}), 1.62-1.67(\mathrm{~m}, 4 \mathrm{H}), 1.91-1.97(\mathrm{~m}, 4 \mathrm{H}), 3.62(\mathrm{t}, J=7.2 \mathrm{~Hz}, 2 \mathrm{H}), 3.72(\mathrm{t}, J=7.6 \mathrm{~Hz}$, 2H), $6.93(\mathrm{t}, J=9.4 \mathrm{~Hz}, 1 \mathrm{H}), 7.24(\mathrm{t}, J=9.2 \mathrm{~Hz}, 1 \mathrm{H}), 7.33-7.45(\mathrm{~m}, 3 \mathrm{H}), 7.52-7.61(\mathrm{~m}, 4 \mathrm{H}), 7.70$ $(\mathrm{d}, J=8.0 \mathrm{~Hz}, 1 \mathrm{H}), 7.77(\mathrm{~d}, J=8.4 \mathrm{~Hz}, 1 \mathrm{H}), 7.83(\mathrm{~d}, J=8.0 \mathrm{~Hz}, 1 \mathrm{H}), 8.21(\mathrm{~d}, J=8.0 \mathrm{~Hz}, 1 \mathrm{H})$, $8.28(\mathrm{~d}, J=8.0 \mathrm{~Hz}, 1 \mathrm{H}), 8.72(\mathrm{~d}, J=8.4 \mathrm{~Hz}, 1 \mathrm{H}), 9.13(\mathrm{~s}, 1 \mathrm{H}), 10.53$ (s, 1H), 11.07 (s, 1H), 11.35 (s, 1H),11.95 (s, 1H); ${ }^{13} \mathrm{C}\left\{{ }^{1} \mathrm{H}\right\}$ NMR (75 MHz, DMSO-d $\left.6,25{ }^{\circ} \mathrm{C}, \mathrm{TMS}\right): \delta 14.0,14.1,22.3,22.4$, 
28.4, 28.5, 28.8, 28.9, 31.6, 31.7, 101.5, 108.6, 110.9, 111.2, 112.3, 113.3, 116.3, 117.8, 118.5, 118.6, 119.1, 120.6, 120.8, 121.1, 121.2, 121.3, 121.5, 121.9, 122.1, 122.2, 122.5, 122.9, 124.4, $125.5,125.9,126.4,126.8,129.5,134.4,135.0,135.5,138.4,140.0,141.4,141.5,141.6,143.2$, 147.9, 149.1; HRMS (ESI-TOF) m/z: [M] ${ }^{+}$Calcd. for $\mathrm{C}_{50} \mathrm{H}_{43} \mathrm{BF}_{2} \mathrm{~N}_{6}$ : 776.3610; Found: 776.3591.

Compound 8. Dye 8 was prepared by reaction of $6(150 \mathrm{mg}, 0.21 \mathrm{mmol}), \mathrm{Et}_{3} \mathrm{~N}(0.43 \mathrm{~mL}, 1.2$ $\mathrm{mmol})$ and $\mathrm{BF}_{3} \cdot \mathrm{OEt}_{2}(0.15 \mathrm{~mL}, 1.2 \mathrm{mmol})$ in $15 \mathrm{~mL} \mathrm{DCE}$ according to the general procedure. Crude product was purified by column chromatography (silica gel, DCM/petroleum ether, 50:50) to furnish pure $8\left(102 \mathrm{mg}, 60 \%\right.$ ) as blue solid. $\mathrm{Mp}:>300.0{ }^{\circ} \mathrm{C}$; IR (neat, $\mathrm{cm}^{-1}$ ): 3429, 1567, 1509, 1320, 1220, 941, 745; ${ }^{1} \mathrm{H}$ NMR (300 MHz, DMSO-d $\left.6,25{ }^{\circ} \mathrm{C}, \mathrm{TMS}\right): \delta 0.91$ (t, $\left.J=7.2 \mathrm{~Hz}, 6 \mathrm{H}\right)$, 1.36-1.47 (m, 4H), 1.58-1.68 (m, 4H), 1.87-1.97 (m, 4H), $3.70(\mathrm{t}, J=7.5 \mathrm{~Hz}, 4 \mathrm{H}), 7.31-7.42$ (m, $4 \mathrm{H}), 7.51-7.65(\mathrm{~m}, 4 \mathrm{H}), 7.83(\mathrm{t}, J=8.4 \mathrm{~Hz}, 4 \mathrm{H}), 8.26(\mathrm{~d}, J=8.1 \mathrm{~Hz}, 2 \mathrm{H}), 8.55(\mathrm{~d}, J=8.4 \mathrm{~Hz}, 2 \mathrm{H})$, 10.17 (s, 2H), 12.03 (s, 2H); ${ }^{13} \mathrm{C}\left\{{ }^{1} \mathrm{H}\right\}$ NMR could not be done due to poor solubility; HRMS (ESITOF) $\mathrm{m} / \mathrm{z}$ : $[\mathrm{M}]^{+}$Calcd. for $\mathrm{C}_{50} \mathrm{H}_{42} \mathrm{~B}_{2} \mathrm{~F}_{4} \mathrm{~N}_{6}$ : 824.3604; Found: 824.3635. Anal. calcd. for $\mathrm{C}_{50} \mathrm{H}_{42} \mathrm{~B}_{2} \mathrm{~F}_{4} \mathrm{~N}_{6}$ : C, 72.83; H, 5.13; N, 10.19\%. Found: C, 72.59; H, 5.32; N, 9.89\%.

Compound 5b. A mixture of 4 (150 mg, $0.36 \mathrm{mmol})$ and triphenylborane (105 $\mathrm{mg}, 0.43 \mathrm{mmol})$ in toluene $(15 \mathrm{~mL})$ was heated $\left(90^{\circ} \mathrm{C}\right)$ under inert atmosphere for $12 \mathrm{~h}$. The mixture was allowed to cool down, and the solvent was removed in a rotary evaporator. Crude product was purified by column chromatography (silica gel, DCM/petroleum ether, 40:60) to furnish pure $\mathbf{5 b}$ (94 mg, 45\%) as orange solid. Mp: $199.0{ }^{\circ} \mathrm{C}$; ${ }^{1} \mathrm{H}$ NMR $\left(300 \mathrm{MHz},\left(\mathrm{CD}_{3}\right)_{2} \mathrm{CO}, 25^{\circ} \mathrm{C}, \mathrm{TMS}\right): \delta 0.91(\mathrm{t}, J=7.2 \mathrm{~Hz}$, $3 \mathrm{H}), 1.38-1.46(\mathrm{~m}, 2 \mathrm{H}), 1.59-1.65(\mathrm{~m}, 2 \mathrm{H}), 1.88-1.94(\mathrm{~m}, 2 \mathrm{H}), 2.18(\mathrm{~s}, 3 \mathrm{H}), 3.54(\mathrm{t}, J=7.8 \mathrm{~Hz}$, 2H), 6.50-6.53 (m, 1H), 6.99-7.18 (m, 9H), 7.37-7.46 (m, 6H), $7.55(\mathrm{~d}, J=8.4 \mathrm{~Hz}, 1 \mathrm{H}), 8.10-8.17$ $(\mathrm{m}, 2 \mathrm{H}), 8.24(\mathrm{~d}, J=8.1 \mathrm{~Hz}, 1 \mathrm{H}), 8.71(\mathrm{~d}, J=8.1 \mathrm{~Hz}, 1 \mathrm{H}), 10.60(\mathrm{~s}, 1 \mathrm{H}) ;{ }^{13} \mathrm{C}\left\{{ }^{1} \mathrm{H}\right\} \mathrm{NMR}(75 \mathrm{MHz}$, $\left.\left(\mathrm{CD}_{3}\right)_{2} \mathrm{CO}, 25^{\circ} \mathrm{C}, \mathrm{TMS}\right): \delta 14.4,23.4,26.8,33.1,107.5,112.4,115.2,118.1,118.6,118.8,122.4$, $122.8,123.4,123.6,125.5,125.7,126.2,126.4,126.5,126.9,128.2,134.4,136.3,140.6,141.4$, 142.4, 147.6, 153.2, 159.4; HRMS (ESI-TOF) m/z: [M] ${ }^{+}$Calcd. for $\mathrm{C}_{41} \mathrm{H}_{36} \mathrm{BN}_{3}$ : 581.3002; Found: 581.3068. Anal. calcd. for $\mathrm{C}_{41} \mathrm{H}_{36} \mathrm{BN}_{3}$ : C, 84.68; H, 6.24; N, 7.23\%. Found: C, 84.41; H, 6.11; N, $6.97 \%$. 
Compound 7b. A mixture of 6 (150 mg, $0.21 \mathrm{mmol})$ and triphenylborane (119 $\mathrm{mg}, 0.49 \mathrm{mmol})$ in toluene $(10 \mathrm{~mL})$ was heated $\left(90^{\circ} \mathrm{C}\right)$ under inert atmosphere for $48 \mathrm{~h}$. The mixture was allowed to cool down, and the solvent was removed in a rotary evaporator. Crude product was purified by column chromatography (silica gel, DCM/petroleum ether, 40:60) to furnish pure $7 \mathbf{b}$ (46 mg, 25\%) as blue solid. Mp: $>300.0{ }^{\circ} \mathrm{C} ;{ }^{1} \mathrm{H}$ NMR (400 MHz, $\left.\left(\mathrm{CD}_{3}\right)_{2} \mathrm{CO}, 25{ }^{\circ} \mathrm{C}, \mathrm{TMS}\right): \delta 0.87-0.98(\mathrm{~m}, 6 \mathrm{H})$, 1.45-1.50 (m, 4H), 1.67-1.71 (m, 4H), 1.95-2.06 (m, 4H), $3.61(\mathrm{t}, J=7.2 \mathrm{~Hz}, 2 \mathrm{H}), 3.74(\mathrm{t}, J=7.6$ $\mathrm{Hz}, 2 \mathrm{H}), 6.53(\mathrm{~d}, J=8.4 \mathrm{~Hz}, 1 \mathrm{H}), 6.94(\mathrm{t}, J=8.1 \mathrm{~Hz}, 1 \mathrm{H}), 7.06-7.23(\mathrm{~m}, 9 \mathrm{H}), 7.34-7.39(\mathrm{~m}, 6 \mathrm{H})$, 7.49-7.69 (m, 3H), $7.88(\mathrm{~d}, J=8.0 \mathrm{~Hz}, 1 \mathrm{H}), 8.25(\mathrm{~d}, J=8.0 \mathrm{~Hz}, 1 \mathrm{H}), 8.29$ (t, $J=8.0 \mathrm{~Hz}, 1 \mathrm{H}), 8.60$ $(\mathrm{d}, J=8.4 \mathrm{~Hz}, 1 \mathrm{H}), 8.70(\mathrm{~s}, 1 \mathrm{H}), 10.45-10.49(\mathrm{~m}, 3 \mathrm{H}), 10.94(\mathrm{~s}, 1 \mathrm{H}) ;{ }^{13} \mathrm{C}\left\{{ }^{1} \mathrm{H}\right\} \mathrm{NMR}(75 \mathrm{MHz}$, $\left.\left(\mathrm{CD}_{3}\right)_{2} \mathrm{CO}, 25^{\circ} \mathrm{C}, \mathrm{TMS}\right): \delta 14.4,14.5,23.5,33.1,104.9,109.9,111.7,111.8,112.8,115.1,117.7$, 119.0, 119.3, 119.7, 120.3, 122.0, 122.3, 122.8, 122.9, 123.0, 123.1, 123.2, 123.3, 123.7, 123.8, $125.9,126.0,126.3,126.8,127.2,127.6,128.4,129.3,135.0,135.6,136.2,136.4,138.5,142.4$, 142.5, 142.6, 142.8, 143.3, 147.2, 148.0, 150.5; HRMS (ESI-TOF) m/z: [M] Calcd. for $\mathrm{C}_{62} \mathrm{H}_{53} \mathrm{BN}_{6}: 892.4425$; Found: 892.4395 .

Compound 10. To a solution of $9(850 \mathrm{mg}, 1.76 \mathrm{mmol})$ in a THF/ $\mathrm{H}_{2} \mathrm{O}(5: 2,60 \mathrm{~mL})$, anhydrous $\mathrm{FeBr}_{3}(1.56 \mathrm{~g}, 5.27 \mathrm{mmol})$ was added portion wise under $\mathrm{N}_{2}$ atmosphere at $25^{\circ} \mathrm{C}$ and the mixture was stirred for $20 \mathrm{~h}$. Then, $\mathrm{H}_{2} \mathrm{O}(30 \mathrm{~mL})$ was added, and the mixture was extracted with EtOAc. The organic layer was washed with brine $(25 \mathrm{~mL})$ and dried over anhydrous $\mathrm{Na}_{2} \mathrm{SO}_{4}$. After removal of the solvent under vacuum, the residue was purified by column chromatography (silica gel, $\mathrm{DCM} /$ petroleum ether, 40:60) to furnish pure 10 (930 mg, 94\%) as yellow solid. ${ }^{1} \mathrm{H}$ NMR (400 MHz, DMSO-d $\left.6,25{ }^{\circ} \mathrm{C}, \mathrm{TMS}\right): \delta 0.91(\mathrm{t}, J=7.2 \mathrm{~Hz}, 3 \mathrm{H}), 1.37-1.46(\mathrm{~m}, 2 \mathrm{H}), 1.51-1.59(\mathrm{~m}, 2 \mathrm{H})$, 1.76-1.84 (m, 2H), 3.45 (t, J=7.6 Hz, 2H), 7.54-7.64 (m, 4H), $8.22(\mathrm{~s}, 1 \mathrm{H}), 8.80(\mathrm{~s}, 1 \mathrm{H}), 11.44$ (s, 1H), 11.55 (s, $1 \mathrm{H}) ;{ }^{13} \mathrm{C}\left\{{ }^{1} \mathrm{H}\right\}$ NMR (75 MHz, DMSO-d $\left.6,25{ }^{\circ} \mathrm{C}, \mathrm{TMS}\right): \delta 13.9,22.0,27.8,28.2$, $31.4,93.2$, 109.5, 110.5, 112.8, 113.2, 118.6, 119.0, 120.3, 123.6, 123.7, 124.3, 128.2, 128.6, 134.6, 135.1, 140.0, 140.1. MS (m/z): $559.8[\mathrm{M}]^{+}$; Anal. calcd. for $\mathrm{C}_{23} \mathrm{H}_{19} \mathrm{Br}_{3} \mathrm{~N}_{2}$ : C, 49.06; H, 3.40; N, 4.97\%. Found: C, 48.83; H, 3.52; N, 4.72\%.

Compound 11. A solution of $\mathbf{1 0}(900 \mathrm{mg}, 1.60 \mathrm{mmol})$ and diisopropylamine $(18 \mathrm{~mL})$ in toluene $(18 \mathrm{~mL})$ in a Schlenk flask was purged with argon and then charged with trimethylsilylacetylene (3.3 mL, $24 \mathrm{mmol}), \mathrm{Pd}(\mathrm{dppf})_{2} \mathrm{Cl}_{2}$.DCM (392 mg, $\left.0.48 \mathrm{mmol}\right)$ and $\mathrm{CuI}(91.4 \mathrm{mg}, 0.48 \mathrm{mmol})$ 
respectively. The mixture was heated at $110^{\circ} \mathrm{C}$ for $12 \mathrm{~h}$ under argon. After removal of solvents under vacuum, the crude product was purified by column chromatography (silica gel, $\mathrm{DCM} /$ petroleum ether, 50:50) to furnish $11(800 \mathrm{mg}, 81 \%)$ as a yellowish solid. ${ }^{1} \mathrm{H}$ NMR (400 $\left.\mathrm{MHz}, \mathrm{CDCl}_{3}, 25{ }^{\circ} \mathrm{C}, \mathrm{TMS}\right): \delta 0.28(\mathrm{~s}, 9 \mathrm{H}), 0.30$ (s, 9H), 0.48 (s, 9H), 0.94 (t, $\left.J=7.2 \mathrm{~Hz}, 3 \mathrm{H}\right)$, 1.41-1.51 (m, 2H), 1.57-1.61 (m, 2H), 1.88-1.96 (m, 2H), $3.40(\mathrm{t}, J=8.0 \mathrm{~Hz}, 2 \mathrm{H}), 7.37(\mathrm{~d}, J=8.4$ $\mathrm{Hz}, 1 \mathrm{H}), 7.43$ (d, J=8.0 Hz, 1H), 7.56-7.59 (m, 2H), 8.03 (s, 1H), 8.26 (s, 1H), $8.46(\mathrm{~s}, 1 \mathrm{H}), 8.90$ (s, $1 \mathrm{H}) ;{ }^{13} \mathrm{C}\left\{{ }^{1} \mathrm{H}\right\} \mathrm{NMR}\left(75 \mathrm{MHz}, \mathrm{CDCl}_{3}, 25{ }^{\circ} \mathrm{C}, \mathrm{TMS}\right): \delta-0.6,-0.5,13.2,21.7,27.7,28.1,31.4$, 90.5, 90.8, 93.9, 99.5, 103.1, 105.9, 106.1, 109.3, 109.6, 112.5, 112.8, 118.9, 120.1, 121.1, 122.5, $122.6,125.7,125.9,128.6,128.9,133.2,136.9,139.2,139.6 ; \mathrm{MS}(\mathrm{m} / \mathrm{z}): 614.3[\mathrm{M}]^{+}, 615.4$ $[\mathrm{M}+\mathrm{H}]^{+}$; Anal. calcd. for $\mathrm{C}_{38} \mathrm{H}_{46} \mathrm{~N}_{2} \mathrm{Si}_{3}: \mathrm{C}, 74.21 ; \mathrm{H}, 7.54 ; \mathrm{N}, 4.55 \%$. Found: C, 74.06; H, 7.69; N, $4.36 \%$.

Compound 12. A mixture of $11(460 \mathrm{mg}, 0.75 \mathrm{mmol})$ and $\mathrm{K}_{2} \mathrm{CO}_{3}(3.1 \mathrm{~g}, 7.50 \mathrm{mmol})$ in $\mathrm{DCM} / \mathrm{MeOH}(1: 1,30 \mathrm{~mL})$ was stirred for $14 \mathrm{~h}$ at $25{ }^{\circ} \mathrm{C}$. The mixture was washed with $\mathrm{H}_{2} \mathrm{O}(50$ $\mathrm{mL}$ X 3), extracted with DCM and dried over anhydrous $\mathrm{Na}_{2} \mathrm{SO}_{4}$. After removal of the solvent under vacuum, the residue was purified by column chromatography (silica gel, DCM/petroleum ether, 50:50) to furnish pure 12 (280 mg, 94\%) as yellow solid. ${ }^{1} \mathrm{H}$ NMR (400 MHz, $\mathrm{CDCl}_{3}, 25$ $\left.{ }^{\circ} \mathrm{C}, \mathrm{TMS}\right): \delta 0.92(\mathrm{t}, J=7.2 \mathrm{~Hz}, 3 \mathrm{H}), 1.37-1.47(\mathrm{~m}, 2 \mathrm{H}), 1.51-1.59(\mathrm{~m}, 2 \mathrm{H}), 1.85-1.93(\mathrm{~m}, 2 \mathrm{H})$, $3.10(\mathrm{~s}, 2 \mathrm{H}), 3.35$ (t, $J=7.6 \mathrm{~Hz}, 2 \mathrm{H}), 3.93(\mathrm{~s}, 1 \mathrm{H}), 7.40$ (d, $J=8.4 \mathrm{~Hz}, 2 \mathrm{H}), 7.57-7.61(\mathrm{~m}, 2 \mathrm{H})$, $8.04(\mathrm{~s}, 1 \mathrm{H}), 8.27(\mathrm{~s}, 1 \mathrm{H}), 8.45(\mathrm{~s}, 1 \mathrm{H}), 8.84(\mathrm{~s}, 1 \mathrm{H}) ;{ }^{13} \mathrm{C}\left\{{ }^{1} \mathrm{H}\right\} \mathrm{NMR}\left(75 \mathrm{MHz}, \mathrm{DMSO}-\mathrm{d}_{6}, 25{ }^{\circ} \mathrm{C}\right.$, TMS): 14.0, 22.1, 28.2, 28.4, 31.5, 78.2, 78.3, 79.5, 85.2, 89.4, 93.1, 110.8, 111.3, 111.4, 111.5, $119.5,120.9,121.5,122.1,122.3,125.0,125.7,129.1,129.6,134.2,138.4,141.0,141.1$; MS $(\mathrm{m} / \mathrm{z}): 398.1[\mathrm{M}]^{+}$. Anal. calcd. for $\mathrm{C}_{29} \mathrm{H}_{22} \mathrm{~N}_{2}: \mathrm{C}, 87.41 ; \mathrm{H}, 5.56 ; \mathrm{N}, 7.03 \%$. Found: $\mathrm{C}, 87.74 ; \mathrm{H}$, $5.57 ; \mathrm{N}, 6.73 \%$.

Compound 13. To a stirred, degassed DCM/EtOH (1:1, $40 \mathrm{~mL})$ solution of 12 (280 mg, 0.70 mmol) was added under argon $\mathrm{Pd} / \mathrm{C} 10 \%$ (60 mg, 20\% mol.). The reaction mixture was stirred at $50{ }^{\circ} \mathrm{C}$ under $\mathrm{H}_{2}$ (atmospheric pressure) for $24 \mathrm{~h}$. After that, the solution was filtered through Celite and the solvent was evaporated. The crude mixture was purified by column chromatography (silica gel, DCM/petroleum ether, 40:60) to furnish pure $13(240 \mathrm{mg}, 85 \%)$ as yellow solid. ${ }^{1} \mathrm{H}$ NMR (400 MHz, DMSO-d $\left.6,25^{\circ} \mathrm{C}, \mathrm{TMS}\right): \delta 0.91(\mathrm{t}, J=7.2 \mathrm{~Hz}, 3 \mathrm{H}), 1.28-1.32(\mathrm{~m}, 6 \mathrm{H}), 1.38-1.47$ (m, $5 \mathrm{H}), 1.55-1.63(\mathrm{~m}, 2 \mathrm{H}), 1.76-1.84(\mathrm{~m}, 2 \mathrm{H}), 2.76-2.82(\mathrm{~m}, 4 \mathrm{H}), 3.41-3.51(\mathrm{~m}, 4 \mathrm{H}), 7.22-7.24(\mathrm{~m}$, 
2H), 7.40-7.43 (m, 2H), $7.91(\mathrm{~s}, 1 \mathrm{H}), 7.95(\mathrm{~s}, 1 \mathrm{H}), 10.76(\mathrm{~s}, 1 \mathrm{H}), 10.80(\mathrm{~s}, 1 \mathrm{H}) ;{ }^{13} \mathrm{C}\left\{{ }^{1} \mathrm{H}\right\} \mathrm{NMR}(75$ MHz, DMSO-d $6,25{ }^{\circ} \mathrm{C}$, TMS): $\delta 13.8,14.0,16.4,16.7,21.2,22.2,28.1,28.5,28.7,31.7,110.2$, $115.1,116.4,119.3,119.6,120.4,122.8,123.0,124.8,132.6,132.8,134.1,134.5,139.7$; MS $(\mathrm{m} / \mathrm{z}): 410.2[\mathrm{M}]^{+}$; Anal. calcd. for $\mathrm{C}_{29} \mathrm{H}_{34} \mathrm{~N}_{2}: \mathrm{C}, 84.83 ; \mathrm{H}, 8.35 ; \mathrm{N}, 6.82 \%$. Found: $\mathrm{C}, 84.50 ; \mathrm{H}$, $8.31 ; \mathrm{N}, 6.79 \%$.

Compound 14. To a solution of $\mathbf{1 3}(250 \mathrm{mg}, 0.61 \mathrm{mmol})$ in $\mathrm{AcOH}(5 \mathrm{~mL}), \mathrm{Br}_{2}$ (195 mg, 1.22 $\mathrm{mmol})$ in $\mathrm{AcOH}(2 \mathrm{~mL})$ was added dropwise at $25^{\circ} \mathrm{C}$ during 30 mins. Then the mixture was stirred at $100{ }^{\circ} \mathrm{C}$ for $2 \mathrm{~h}$. The reaction was quenched with aq. $\mathrm{Na}_{2} \mathrm{SO}_{3}$ and extracted with $\mathrm{DCM}$. The organic layer was washed with $\mathrm{NaHCO}_{3}\left(20 \mathrm{~mL} \mathrm{X} \mathrm{2)}\right.$ and $\mathrm{H}_{2} \mathrm{O}(30 \mathrm{~mL}$ X 3) and, dried over anhydrous $\mathrm{Na}_{2} \mathrm{SO}_{4}$. After removal of the solvent under vacuum, the residue was purified by column chromatography (silica gel, DCM/petroleum ether, 20:80) to furnish pure 14 (320 mg, 92\%) as yellow solid. ${ }^{1} \mathrm{H}$ NMR (400 MHz, DMSO-d $\left.6,25{ }^{\circ} \mathrm{C}, \mathrm{TMS}\right): \delta 0.90$ (t, $J=7.2 \mathrm{~Hz}, 3 \mathrm{H}$ ), 1.28-1.32 (m, 6H), 1.36-1.46 (m, 5H), 1.56-1.63 (m, 2H), 1.72-1.79 (m, 2H), 2.78-2.83 (m, 4H), 3.56-3.65 (m, 4H), $7.49(\mathrm{~s}, 2 \mathrm{H}), 7.93(\mathrm{~s}, 1 \mathrm{H}), 8.00(\mathrm{~s}, 1 \mathrm{H}), 10.50(\mathrm{~s}, 1 \mathrm{H}), 10.57(\mathrm{~s}, 1 \mathrm{H}) ;{ }^{13} \mathrm{C}\left\{{ }^{1} \mathrm{H}\right\}$ NMR (75 MHz, DMSO-d $6,25{ }^{\circ} \mathrm{C}$, TMS): $\delta$ 13.8, 14.0, 16.2, 16.5, 20.5, 22.2, 27.4, 27.9, 28.0, 28.6, 31.6 102.9, 103.0, 117.0, 118.3, 120.0, 120.2, 120.5, 120.7, 124.8, 125.0, 127.6, 127.7, 134.5, 134.9, 135.1, 135.3, 138.0; MS (m/z): 566.2 [M] ${ }^{+}$; Anal. calcd. for $\mathrm{C}_{29} \mathrm{H}_{32} \mathrm{Br}_{2} \mathrm{~N}_{2}: \mathrm{C}, 61.28 ; \mathrm{H}, 5.67$; N, 4.93\%. Found: C, 61.03; H, 5.59; N, 4.69\%.

Compound 15. A solution of $14(250 \mathrm{mg}, 0.44 \mathrm{mmol})$ in 1,4-dioxane (20 mL) in a Schlenk flask was purged with argon and then charged with pinacolborane $(0.64 \mathrm{~mL}, 4.4 \mathrm{mmol}), \mathrm{Et}_{3} \mathrm{~N}(1.33 \mathrm{~mL})$ and $\mathrm{Pd}\left(\mathrm{PPh}_{3}\right)_{2} \mathrm{Cl}_{2}(62.0 \mathrm{mg}, 0.09 \mathrm{mmol})$ respectively. The mixture was stirred at reflux for $12 \mathrm{~h}$ under argon. After removal of solvents under vacuum, the crude product was purified by column chromatography (silica gel, DCM/petroleum ether, 40:60) to furnish 15 (204 $\mathrm{mg}, 70 \%$ ) as a yellowish solid. ${ }^{1} \mathrm{H} \mathrm{NMR}\left(300 \mathrm{MHz}, \mathrm{CDCl}_{3}, 25{ }^{\circ} \mathrm{C}, \mathrm{TMS}\right): \delta 0.96(\mathrm{t}, J=7.2 \mathrm{~Hz}, 3 \mathrm{H}), 1.39(\mathrm{t}, J=$ $7.5 \mathrm{~Hz}, 6 \mathrm{H}), 1.48(\mathrm{~s}, 24 \mathrm{H}), 1.53-1.63(\mathrm{~m}, 7 \mathrm{H}), 1.95-2.04(\mathrm{~m}, 2 \mathrm{H}), 2.88(\mathrm{q}, J=7.5 \mathrm{~Hz}, 4 \mathrm{H}), 3.46-$ $3.56(\mathrm{~m}, 4 \mathrm{H}), 7.72(\mathrm{~s}, 2 \mathrm{H}), 8.15(\mathrm{~s}, 1 \mathrm{H}), 8.17(\mathrm{~s}, 1 \mathrm{H}), 9.19(\mathrm{~s}, 1 \mathrm{H}), 9.23(\mathrm{~s}, 1 \mathrm{H}) ;{ }^{13} \mathrm{C}\left\{{ }^{1} \mathrm{H}\right\} \mathrm{NMR}(75$ $\left.\mathrm{MHz}, \mathrm{CDCl}_{3}, 25^{\circ} \mathrm{C}, \mathrm{TMS}\right): \delta 13.4,14.2,16.9,17.1,22.1,22.7,25.1,28.8,29.1,29.2,32.3,83.8$, $115.5,116.7,119.5,119.9,123.1,123.2,124.9,125.0,131.7,131.8,133.6,133.7,134.0,134.6$, 
145.0, 145.1; MS (m/z): $662.5[\mathrm{M}]^{+}$; Anal. calcd. for $\mathrm{C}_{41} \mathrm{H}_{56} \mathrm{~B}_{2} \mathrm{~N}_{2} \mathrm{O}_{4}: \mathrm{C}, 74.33 ; \mathrm{H}, 8.52 ; \mathrm{N}, 4.23 \%$. Found: C, 74.24; H, 8.49; N, 4.26\%.

Compound 16. 1st step: A mixture of 15 (90 mg, $0.14 \mathrm{mmol})$, 2-bromo-5-methylpyridine (56.0 $\mathrm{mg}, 0.33 \mathrm{mmol}), \mathrm{Pd}\left(\mathrm{PPh}_{3}\right)_{4}(31 \mathrm{mg}, 0.03 \mathrm{mmol}), \mathrm{Cs}_{2} \mathrm{CO}_{3}(213 \mathrm{mg}, 0.65 \mathrm{mmol})$ and $\mathrm{CsF}(99 \mathrm{mg}$, $0.3 \mathrm{mmol})$ in dry toluene/DMF $(2 / 1, \mathrm{v} / \mathrm{v}, 6 \mathrm{~mL})$ in a Schlenk flask was degassed thoroughly and then stirred at $90^{\circ} \mathrm{C}$ for $12 \mathrm{~h}$ under argon. The reaction was quenched with water, and the mixture was extracted with DCM. The organic layer was dried over anhydrous $\mathrm{Na}_{2} \mathrm{SO}_{4}$. After removal of solvent under vacuum, the crude product $(72 \mathrm{mg}$ ) was obtained which was pure enough to use for the next step without further purification.

2nd step: In a solution of the crude obtained from $1^{\text {st }}$ step $(72 \mathrm{mg}, 0.12 \mathrm{mmol})$ in DCE (10 $\mathrm{mL})$ was added $\mathrm{Et}_{3} \mathrm{~N}(0.17 \mathrm{~mL}, 1.18 \mathrm{mmol})$ and the mixture was stirred at $25{ }^{\circ} \mathrm{C}$ for $15 \mathrm{~min}$. $\mathrm{BF}_{3} \cdot \mathrm{OEt}_{2}(0.15 \mathrm{~mL}, 1.18 \mathrm{mmol})$ was added dropwise into it and the reaction mixture was stirred at $80{ }^{\circ} \mathrm{C}$ for $12 \mathrm{~h}$ under argon and then cooled to room temperature. The reaction was quenched with aq. $\mathrm{NaHCO}_{3}(20 \mathrm{~mL})$ and extracted with DCM $(30 \mathrm{~mL})$. The organic layer was washed with $\mathrm{H}_{2} \mathrm{O}(50 \mathrm{~mL} X 3)$ and dried over anhydrous $\mathrm{Na}_{2} \mathrm{SO}_{4}$. After removal of the solvent under vacuum, the residue was purified by column chromatography (silica gel, DCM/petroleum ether, 50:50) to furnish pure 16 (67 mg, 72\%) as orange solid. Mp: $>300.0^{\circ} \mathrm{C}$; IR (neat, $\mathrm{cm}^{-1}$ ): 1631, 1563, 1515, 1484, 1063, 724; ${ }^{1} \mathrm{H}$ NMR (400 MHz, $\mathrm{C}_{2} \mathrm{D}_{2} \mathrm{Cl}_{4}, 25{ }^{\circ} \mathrm{C}$, TMS): $\delta 1.09$ (t, $J=7.6 \mathrm{~Hz}, 3 \mathrm{H}$ ), 1.50-1.54 $(\mathrm{m}, 10 \mathrm{H}), 1.60-1.69(\mathrm{~m}, 5 \mathrm{H}), 1.83-1.91(\mathrm{~m}, 2 \mathrm{H}), 2.02-2.09(\mathrm{~m}, 2 \mathrm{H}), 2.60(\mathrm{~s}, 6 \mathrm{H}), 3.14-3.21$ (m, 2H), 7.91 (s, 2H), 7.97 (d, $J=8.4 \mathrm{~Hz}, 2 \mathrm{H}), 8.31$ (d, $J=8.4 \mathrm{~Hz}, 2 \mathrm{H}), 8.41(\mathrm{~s}, 1 \mathrm{H}), 8.46(\mathrm{~s}, 1 \mathrm{H})$, 8.89 (s, $2 \mathrm{H}) .{ }^{13} \mathrm{C}\left\{{ }^{1} \mathrm{H}\right\}$ NMR could not be done due to poor solubility; HRMS (ESI-TOF) m/z: [M]+ Calcd. for $\mathrm{C}_{41} \mathrm{H}_{42} \mathrm{~B}_{2} \mathrm{~F}_{4} \mathrm{~N}_{4}$ : 688.3532; Found: 688.3599. Anal. calcd. for $\mathrm{C}_{41} \mathrm{H}_{42} \mathrm{~B}_{2} \mathrm{~F}_{4} \mathrm{~N}_{4}$ : C, 71.53; H, 6.15; N, 8.14\%. Found: C, 71.34; H, 6.29; N, 8.01\%.

Supporting Information: Copies of the ${ }^{1} \mathrm{H}$ NMR and ${ }^{13} \mathrm{C}\left\{{ }^{1} \mathrm{H}\right\}$ NMR spectra of the synthesized compounds, Cyclic voltammograms, X-ray crystallographic and Computational data (PDF). X-ray crystallographic data for 5a (CIF). This material is available free of charge via the Internet at http://pubs.acs.org. 
Acknowledgement: S.M. is very grateful to French National Agency (ORION project ANR-13PRGE-0001) for the financial support and to Bhabha Atomic Research Centre for the permission to conduct research in France.

\section{References:}

1. Wakamiya, A.; Mori, K.; Yamaguchi, S. 3-Boryl-2,2'-bithiophene as a Versatile Core Skeleton for Full-Color Highly Emissive Organic Solids. Angew. Chem. Int. Ed. 2007, 46, 4273 4276.

2. Elbing, M.; Bazan, G. C. A New Design Strategy for Organic Optoelectronic Materials by Lateral Boryl Substitution. Angew. Chem. Int. Ed. 2008, 47, 834-838.

3. Jäkle, F. Advances in the Synthesis of Organoborane Polymers for Optical, Electronic, and Sensory Applications. Chem. Rev. 2010, 110, 3985-4022.

4. Araneda, J. F.; Neue, B.; Piers, W. E. Enforced Planarity: A Strategy for Stable BoronContaining $\pi$-Conjugated Materials. Angew. Chem. Int. Ed. 2012, 51, 9977-9979.

5. Zhou, Z.; Wakamiya, A.; Kushida, T.; Yamaguchi, S. Planarized Triarylboranes: Stabilization by Structural Constraint and Their Plane-to-Bowl Conversion. J. Am. Chem. Soc. 2012, 134, 4529-4532.

6. Saito, S.; Matsuo, K.; Yamaguchi, S. Polycyclic $\pi$-Electron System with Boron at Its Center. J. Am. Chem. Soc. 2012, 134, 9130-9133.

7. Iida, A.; Saito, S.; Sasamori, T.; Yamaguchi, S. Borylated Dibenzoborepin: Synthesis by Skeletal Rearrangement and Photochromism Based on Bora-Nazarov Cyclization. Angew. Chem. Int. Ed. 2013, 52, 3760-3764.

8. Bessette, A.; Hanan, G. S. Design, synthesis and photophysical studies of dipyrromethenebased materials: insights into their applications in organic photovoltaic devices. Chem. Soc. Rev. 2014, 43, 3342-3405.

9. Loudet, A.; Burgess, K. BODIPY Dyes and Their Derivatives: Syntheses and Spectroscopic Properties. Chem. Rev. 2007, 107, 4891-4932.

10. Ulrich, G.; Ziessel, R.; Harriman, A. The Chemistry of Fluorescent Bodipy Dyes: Versatility Unsurpassed. Angew. Chem. Int. Ed. 2008, 47, 1184-1201.

11. Bura, T.; Leclerc, N.; Fall, S.; Lévêque, P.; Heiser, T.; Retailleau, P.; Rihn, S.; Mirloup, A.; Ziessel, R. High-Performance Solution-Processed Solar Cells and Ambipolar Behavior in 
Organic Field-Effect Transistors with Thienyl-BODIPY Scaffoldings. J. Am. Chem. Soc. 2012, 134, 17404-17407.

12. Mirloup, A.; Leclerc, N.; Rihn, S.; Bura, T.; Bechara, R.; Hebraud, A.; Leveque, P.; Heiser, T.; Ziessel, R. A deep-purple-grey thiophene-benzothiadiazole-thiophene BODIPY dye for solution-processed solar cells. New J. Chem. 2014, 38, 3644-3653.

13. Mirloup, A.; Huaulme, Q.; Leclerc, N.; Leveque, P.; Heiser, T.; Retailleau, P.; Ziessel, R. Thienyl-BOPHY dyes as promising templates for bulk heterojunction solar cells. Chem. Commun. 2015, 51, 14742-14745.

14. Bulut, I.; Huaulmé, Q.; Mirloup, A.; Chávez, P.; Fall, S.; Hébraud, A.; Méry, S.; Heinrich, B.; Heiser, T.; Lévêque, P.; Leclerc, N. Rational Engineering of BODIPY-Bridged Trisindole Derivatives for Solar Cell Applications. ChemSusChem 2017, 10, 1878-1882.

15. Bucher, L.; Desbois, N.; Harvey Pierre, D.; Sharma Ganesh, D.; Gros Claude, P. Porphyrins and BODIPY as Building Blocks for Efficient Donor Materials in Bulk Heterojunction Solar Cells. Solar RRL 2017, 1, 1700127.

16. Mula, S.; Ray, A. K.; Banerjee, M.; Chaudhuri, T.; Dasgupta, K.; Chattopadhyay, S. Design and Development of a New Pyrromethene Dye with Improved Photostability and Lasing Efficiency: Theoretical Rationalization of Photophysical and Photochemical Properties. J. Org. Chem. 2008, 73, 2146-2154.

17. Jagtap, K. K.; Shivran, N.; Mula, S.; Naik, D. B.; Sarkar, S. K.; Mukherjee, T.; Maity, D. K.; Ray, A. K. Change of Boron Substitution Improves the Lasing Performance of Bodipy Dyes: A Mechanistic Rationalisation. Chem. - Eur. J. 2012, 19, 702-708.

18. Araneda, J. F.; Piers, W. E.; Heyne, B.; Parvez, M.; McDonald, R. High Stokes Shift Anilido-Pyridine Boron Difluoride Dyes. Angew. Chem. Int. Ed. 2011, 50, 12214-12217.

19. Jin, J.-L.; Li, H.-B.; Geng, Y.; Wu, Y.; Duan, Y.-A.; Su, Z.-M. Theoretical Insight into the Origin of Large Stokes Shift and Photophysical Properties of Anilido-Pyridine Boron Difluoride Dyes. ChemPhysChem 2012, 13, 3714-3722.

20. Hao, Q.; Yu, S.; Li, S.; Chen, J.; Zeng, Y.; Yu, T.; Yang, G.; Li, Y. Locked Planarity: A Strategy for Tailoring Ladder-Type $\pi$-Conjugated Anilido-Pyridine Boron Difluorides. $J$. Org. Chem. 2014, 79 , 459-464.

21. Janosik, T.; Rannug, A.; Rannug, U.; Wahlström, N.; Slätt, J.; Bergman, J. Chemistry and Properties of Indolocarbazoles. Chem. Rev. 2018, 118, 9058-9128. 
22. Mahapatra, A. K.; Hazra, G.; Sahoo, P. Synthesis of indolo[3,2-b]carbazole-based new colorimetric receptor for anions: A unique color change for fluoride ions. Beilstein J. Org. Chem. 2010, 6,12 .

23. Gillner, M.; Bergman, J.; Cambillau, C.; Alexandersson, M.; Fernström, B.; Gustafsson, J. A. Interactions of indolo[3,2-b]carbazoles and related polycyclic aromatic hydrocarbons with specific binding sites for 2,3,7,8-tetrachlorodibenzo-p-dioxin in rat liver. J. Biol. Chem. 1993, 44, 336-345.

24. Chen, Y.-H.; Riby, J.; Srivastava, P.; Bartholomew, J.; Denison, M.; Bjeldanes, L. Regulation of CYP1A1 by Indolo[3,2-b]carbazole in Murine Hepatoma Cells. J. Biol. Chem. 1995, $270,22548-22555$.

25. Herrmann, S.; Seidelin, M.; Bisgaard, H. C.; Vang, O. Indolo[3,2-b]carbazole inhibits gap junctional intercellular communication in rat primary hepatocytes and acts as a potential tumor promoter. Carcinogenesis 2002, 23, 1861-1868.

26. Boudreault, P.-L. T.; Wakim, S.; Blouin, N.; Simard, M.; Tessier, C.; Tao, Y.; Leclerc, M. Synthesis, Characterization, and Application of Indolo[3,2-b]carbazole Semiconductors. J. Am. Chem. Soc. 2007, 129 , 9125-9136.

27. Guo, Y.; Zhao, H.; Yu, G.; Di, C.-A.; Liu, W.; Jiang, S.; Yan, S.; Wang, C.; Zhang, H.; Sun, X.; Tao, X.; Liu, Y. Single-Crystal Microribbons of an Indolo[3,2-b]carbazole Derivative by Solution-Phase Self-Assembly with Novel Mechanical, Electrical, and Optical Properties. Adv. Mater. 2008, 20 , 4835-4839.

28. Reig, M.; Puigdollers, J.; Velasco, D. Molecular order of air-stable p-type organic thinfilm transistors by tuning the extension of the [small pi]-conjugated core: the cases of indolo[3,2b]carbazole and triindole semiconductors. J. Mater. Chem. C 2015, 3, 506-513.

29. Zhao, H.-P.; Tao, X.-T.; Wang, F.-Z.; Ren, Y.; Sun, X.-Q.; Yang, J.-X.; Yan, Y.-X.; Zou, D.-C.; Zhao, X.; Jiang, M.-H. Structure and electronic properties of triphenylamine-substituted indolo[3,2-b]carbazole derivatives as hole-transporting materials for organic light-emitting diodes. Chem. Phys. Lett. 2007, 439 , 132-137.

30. Zhao, H.-P.; Wang, F.-Z.; Yuan, C.-X.; Tao, X.-T.; Sun, J.-L.; Zou, D.-C.; Jiang, M.-H. Indolo[3,2-b]carbazole: Promising building block for highly efficient electroluminescent materials. Org. Electron. 2009, $10,925-931$. 
31. Svetlichnyi, V. M.; Alexandrova, E. L.; Miagkova, L. A.; Matushina, N. V.; Nekrasova, T. N.; Tameev, A. R.; Stepanenko, S. N.; Vannikov, A. V.; Kudryavtsev, V. V. Photophysical properties of indolo[3,2-b]carbazoles as a promising class of optoelectronic materials. Semiconductors 2010, $44,1581-1587$.

32. Zhang, X.-H.; Wang, Z.-S.; Cui, Y.; Koumura, N.; Furube, A.; Hara, K. Organic Sensitizers Based on Hexylthiophene-Functionalized Indolo[3,2-b]carbazole for Efficient Dye-Sensitized Solar Cells. J. Phys. Chem. C 2009, 113, 13409-13415.

33. Zhou, E.; Cong, J.; Tajima, K.; Hashimoto, K. Synthesis and Photovoltaic Properties of Donor-Acceptor Copolymers Based on 5,8-Dithien-2-yl-2,3-diphenylquinoxaline. Chem. Mater. 2010, 22 , 4890-4895.

34. Xia, Y.; Su, X.; He, Z.; Ren, X.; Wu, H.; Cao, Y.; Fan, D. An Alternating Copolymer Derived from Indolo[3,2-b]carbazole and 4,7-Di(thieno[3,2-b]thien-2-yl)-2,1,3-benzothiadiazole for Photovoltaic Cells. Macromol. Rapid Commun. 2010, 31 , 1287-1292.

35. Chan, L.-H.; Lin, L.-C.; Yao, C.-H.; Liu, Y.-R.; Jiang, Z.-J.; Cho, T.-Y. Synthesis of indolo[3,2-b]carbazole-based random copolymers for polymer solar cell applications. Thin Solid Films 2013, 544, 386-391.

36. Sathiyan, G.; Sivakumar, E. K. T.; Ganesamoorthy, R.; Thangamuthu, R.; Sakthivel, P. Review of carbazole based conjugated molecules for highly efficient organic solar cell application. Tetrahedron Lett. 2016, 57, 243-252.

37. Curiel, D.; Más-Montoya, M.; Usea, L.; Espinosa, A.; Orenes, R. A.; Molina, P. Indolocarbazole-Based Ligands for Ladder-Type Four-Coordinate Boron Complexes. Org. Lett. 2012, $14,3360-3363$.

38. Gu, R.; Hameurlaine, A.; Dehaen, W. Facile One-Pot Synthesis of Novel 6Monosubstituted 5,11-Dihydroindolo[3,2-b]carbazoles and Preparation of Different Derivatives. Synlett 2006, 2006, 1535-1538.

39. Gu, R.; Hameurlaine, A.; Dehaen, W. Facile One-Pot Synthesis of 6-Monosubstituted and 6,12-Disubstituted 5,11-Dihydroindolo[3,2-b]carbazoles and Preparation of Various Functionalized Derivatives. J. Org. Chem. 2007, 72 , 7207-7213.

40. Olmsted, J., Calorimetric determinations of absolute fluorescence quantum yields. $J$. Phys. Chem. 1979, $83,2581-2584$. 
41. Maeda, C.; Todaka, T.; Ema, T. Carbazole-Based Boron Dipyrromethenes (BODIPYs): Facile Synthesis, Structures, and Fine-Tunable Optical Properties. Org. Lett. 2015, 17, 3090-3093. 42. Maeda, C.; Todaka, T.; Ueda, T.; Ema, T. Color-Tunable Solid-State Fluorescence Emission from Carbazole-Based BODIPYs. Chem. - Eur. J. 2016, 22, 7508-7513.

43. Maeda, C.; Nagahata, K.; Ema, T. Carbazole-based BODIPYs with ethynyl substituents at the boron center: solid-state excimer fluorescence in the VIS/NIR region. Org. Biomol. Chem. 2017, 15, 7783-7788.

44. Maeda, C.; Todaka, T.; Ueda, T.; Ema, T. Synthesis of carbazole-based BODIPY dimers showing red fluorescence in the solid state. Org. Biomol. Chem. 2017, 15 , 9283-9287.

45. Goze, C.; Ulrich, G.; Mallon, L. J.; Allen, B. D.; Harriman, A.; Ziessel, R. Synthesis and Photophysical Properties of Borondipyrromethene Dyes Bearing Aryl Substituents at the Boron Center. J. Am. Chem. Soc. 2006, 128, 10231-10239.

46. Kulkarni, A. P.; Tonzola, C. J.; Babel, A.; Jenekhe, S. A. Electron Transport Materials for Organic Light-Emitting Diodes. Chem. Mater. 2004, 16, 4556-4573.

47. Zhang, G.; Musgrave, C. B., Comparison of DFT Methods for Molecular Orbital Eigenvalue Calculations. J. Phys. Chem. A 2007, 111, 1554-1561. 